\title{
Kanunu Bilmemek Özür Sayılmaz kaidesi hakkında bazı düşünceler ${ }^{[1]}$
}

\author{
Yazan : \\ M. G. Derreux \\ Hưkukî ve tktisadî ilimler doktoru, Laon \\ mahkemesinde yargı̨ yardmessı
}

\author{
Çeviren : \\ Jale Gural \\ Ankara Hakak Fakültesi \\ asistanlarından
}

¿Kanunu bilmemek özür sayılmaz» hukuk kaidesi (hukuk meseli) halk tarafından en çok bilinen kaidekerden biridir. Hukuk meselelerinde cahíl olan bir çok kimseler, hị̧ olmazsa her şeyi bilmeleri lâzım geldiğini bilirler ve bu kadar basit olan kaide de dikkatı üzerine çekecek değerde addolunmaz. Bununla beraber sat'î bir görüşle iktifa edilemezse belki de bunun ciddi bir düşünme konusu olabileceğ̀i görülür.

Manş ötesindeki Üniversiteler yüksek bazı kimselere veya hiç hukuk tahsili yapmamış bazı bilginlere sırf itibari olarak fahri hukuk doktoru unvanını verirler, fakat Fransız hukukçusu yukarıda hatırlatmış oldugơumuz kaide sayesinde daha fazlasını yapıyor ve itibari olarak yalnız bazı kimselere deyil, fakat herkese basit bir hukuk doktoru unvanından daha fazla olarak, hukukun tamamı hakkında mükemmel bir bilgi atfediyor. Fakat böyłe bir sanmın (fiction) bizi gerçeklikten (réalité) çok uzaklara götürüp götürmeyeceğini kendi kendimize sorabiliriz. Böyle bir bilgiye malik olmayan ve olmak iddiasinda da bulunmayan kimselere bunu atfetmek tehlikeli olmaz mı? Zoraki hekim ancak komedilerde mevcuttur, zoraki hukukçu gerçeklikte (réalité) yaşamalı mıdır? Hukuk imfihanının daha ilkin de muvaffakiyet göstermiyen talebe, düzgünce konuşamayan, okuma ze yazma bilmeyen köylü, hatta fransızca bilmeden tesadüfen Fransadan geçmekte olan yabancı, bütün kanunları bilir mi addolunacaktır? Şüphesiz mahkeme içtihatları (Jurispru-

[1] Revue. Trimestrielle de Droit Civil - Tome VII, 
dence) ve doktrin adalet gaygusile bu an'anevi kaideden (hukuk meselinden) sadece mantıkî sonuçlar çıkarmaktan çekinmişler* dir. Bu kaide ekseriya tatbik edilirse de her zaman tatbik edilmez. Muayyen bir formül ile bał̆lanmaktan kaçımlır. Bu görüş tarzı; bizi bir dereceye kadar tatmin ederse de yeni bir endişe mevzuu vermez mi? Bize "Her şeyi bilen bir adam" dedikleri zaman ona ne şekilde muamele edeceğimizi açıç̧a biliriz. lâkin bize bu adam her şeyi bilir, fakat megerki fazla bir şeyler bilmesin derlerse tereddüd ve şüphe içinde kalıız. Eğger «Kanunu bilmemek mazeret sayllmaz" kaidesi (hukuk meseli) her zaman tatbik edilmezse, tatbikatçı ona ne zaman istinat edeceğini nasil anlayacaktır? [1]

Bu Etüdümüzün konusu hukukta mevcut olan ve bizim de ortadan kaldırmak istedið̆imiz bu kararsizlıktır.

An'anevî kaideyi (hukuk meselini) tamamile terk etmek yerinde midir? Veya, eğer onu terk etmek yerinde de grilse, ne mikyasta muhafaza etmelidir? Isste halledilecek mesele. Çok ince ve grüç bir mesleki, bu güçlük, meselenin hallinde mıvaffak olamad’ğımız takdirde bizim maazeretimiz olacaktır. Fakat tartışmaya girmeden evvel meselenin sınırlarmı iyice tesbit etmek lâzımdır. Hakikaten çok defa hukukçular, kanunu bilmemek bir özür sayılmaz kaidesine (hukuk meseline); çürütülebilir bir karine mahiyeti vererek zikrederler. Onu bu şekilde anlayış hị̧ bir sanı (fiction) ifade etmediği gibi tenkide de yer vermez. Kendimizi ilgilendirebilecek hukuk kaideleri hakkmna genel olarak bazı bilgrilere sahip olduğumuz çok doğrudur: Çühkü kanun böyle bir aleniyete tabi tutulmuş, etrafımızda hayatın | önemli olaylarına onun karışı̆̆ııı o kadar sık olarak görmüş gazetelerde daima onu beğenen veya tenkit eden o kadar çok makaleler çıkmıştır ki, tereddüt halinde ilgililerin onun hakkında bilgileri olmadıø̆nın kabülünden ziyade, malûmatlarının mevcut olduğunun tahmini daha tabii ve yerindedir; ve bu manada herkes bu kaideyi tasvipte birliktir. Diğer cihetten ve bunun aksine olarak bu kaideye çürütülmesi mümkün olmayan bir karine mahiyeti verilirse uygunlanması, ilgililerin zımmî rızasiyle ortadan kalkabilecek olan bazı kanunlar, açıkça bunun tatbik alanını haricinde kalırlar.

[1] Yuzarların bir çơ̆gu bu bususta hị̧ bir kritệryum göstermezler, diğer Lızliarı ise (ileride görüleceği üzere) bir takım forłnüller iłeri sürerlerse de b.unlarda tenkitten ârî dȩ̧ildirler. 
Meselâ. bir satış akti yapan ve sözleşme (mukavele) masraflarının prensip olarak satıcıya ait olduğunu zanneden iki kişi, satış fiyatı üzerine bu masrafları ilâve ederek onu bu masralar nisbetinde artırabilirler. Böyle bir vaziyette yargıç medeni kanunun 1593 üncü maddesine rałmen sözleșme masrafının satıcıya ait olduğunu kabul etmelidir. Çünkü bu ve buna benzer diğer hukuk kaidelerinin en yüksek gayesi tarafların gizli kalan iradesine mûtlak saygıdır, bu iradeyi kanun namına değiştirmek hakikatte, kanunu ihlâl demek olacaktır [1].

Meselemizin sınırları bu mülâhazalarla tahdit edilmiş olduğundan biz onu şu şekilde ifade edebiliriz: Hiç kimsenin yorumlayıc (tesir edici, interparative hukuk kaidelerinden maada, diğer bir kanun hakkındaki bilgisizlił̧ini (yahut hatasını) isbat etmesine müsaade edilmiyeceği doğru mudur? [2]

Evvelâ bu an'anevi kaidenin (hukuk meselinin) matlak bir surette tatbiki lehinde ileri sürülebilecek delilleri mümkün olduğgu kadar tarafsız bir surette izah edecey̆iz.

Hèr şeyden evvel bunun eski bir kaide oldư̆u göz önünde tutulmalıdır deniliyor. Eski bir kaideyi değiştirmek, meçhul içine atılmak demektir, bu ayn zamanda hukuk bilginlerinin (Jurisconsulte) bu kaideyi pratik hayatın ihtiyaçlarına uydurmak için yapmış oldukları çalışmayı da hiçe indirmektir, bu nihayet. hukuk prensiplerini dȩ̧̛ş̧irmek suretiyle bu değișmenin doğuracă̆ı bir şaşkınlığa atılmaktır.

Diğer taraftan Medenî Kanunun metnide açıktır: "Kanunlar.... Imparatorluğun her tarafında neşr ve ilân edildiklerinin ögrrenilmesi mümkün oldư̆u anda tatbik edilmelidir.» Bundan sonra gelen frkra da (Neşr ve ilân belli bir müddetin geçmesinden sonra herkes tarafından bilinir, addolunur,s Bu belirli (muayyen) müddet, 1804 tarihindenberi değiştirilmiş ise de bu ônemi haiz dę̆ildir. Çünkü kararnamelerle tayin edilen müddetten sonra herkes kanunu bilir addolunur. Portalis «Kanunu bilmenin veya bi-

[1] Cf: Bu manada Cass. req. 11/ocak/1887 D. 885.269

[2] Biz bu etüdümüzde hukukî hatadan veya bir hukukî kaideyi b!̣lmemez* likten ve fili (maddi) hata veya fili (maddi) bir vak'ayı bilmemezlikten; arada bir fark gözetmeksizin ayni şekilde bahsedeceđ̆iz. Hata ile bilgisizlik ayn, ayrı ¥cyler olmakla beraber herkes; tetkik etmekte olduğamuz meselede onların ayn hukukî neticeler meydana getirecergini kabul eder. Aubry ve Rau ya bakın. 5 ed. t. 1. P, 94, not. l. Garraud 2 ed. Traîté de droit pénal. t. I. P. 557 
lebile sek bir durumda bulunmanın> aynı şey olduğunu söylerdi. Medeni Kanunda bu prensibe belirli bazı uygulama alanları vermiştir. Bilhassa «iMahkeme önünde ki ikrardan.... hukukî bir hatadan clolayı geri dönülemez (rucu edilemez) diyeni 356 , "Sulhna* melerin, hukukî hatadan dolayı fesh edilemiyeceğini s söyliyen 2052 inci maddeleriyle. Bu kaidenin taraftarları bundan fazla olarak, biz yalnı kanun metinlerine değil ayn zamanda mantığa da dayarıyoruz diye müdafaalarına devam ederler. Hakikaten akıl (mantık); iki zıd temayül arasında kalmıştır. Bir taraftan kanunla mn yalnız, bunları bilen kimselere uygunlanması istenir, lâkin diger taraftanda apaçık sosyal zaruretler, bunlann herkese tatbikini icabettirir. Bu güçlügü nassl halletmeli ? Görünmez bir uzak bir mesafeden atacağı bir mai ile herkese mükemmel bir hukuk bilgisi aşlayacak bir aletin mevcudiyeti muhakkak surette bu meselenin ideal bir hal çaresini teşkil ederdi. Matteessüf fiiliyatta kanunlár, çok daha fena bir usulie, resmî gazete ile yayımlanırlar. Bundan çıkabilecek zorluğu yok etmek maksadiyle de bir dolambaçlı yola sapmak mecburiyetł kendini gösterir. Hühümet; hukuk kaidelerine mümkün olan en geniş ilân tarzını temin ettiğinden herkesin onları bilir farzedilmesi zaruridir. Bu sam (fiction) o kadar doğrudur ki, iyi bir vatandas kendisini idare eden kanunlaı bilmemezlik edemez, bunları bilmeyen ve bilmedił̣̌ini mahkemeler önünde söylemek suretile bu bilgisizliğinden fatydalanmak isteyen herhengi bir kimse, kendisine şu meşhur «Nemo avditur turpitudinem suam allegaus» işlenen hata size bir lûtuf (menfaat) temin edemez.» kaidesinin hatirlatılmasına lâyik olar.

Ve sonra, acaba bu sanı iddia edildiği kadar da réalitéden uzakmıdır? «Sokaktan geçen bir ameleye; meselâ Hipotek rejimimiz hakkında soru sorduğumuz zaman size bu hususta ne cevap vermesini bekliyebilirsiniz ? , diyen biraz kaba bir sağduyununda fazla tesiri altında kalmamak lâzımdır. Gerçekten, ondan bu hususta bir cevap beklenemez, fakat bu adam kendisine uygunlanması r.ümkün bir kanun hakkında sorguya çekelim, belki de daha iyi bir bilgi sahibdir. Zaten her hangi bir kanunî mesele hakkında daha derin bir bilgi sahibi olmak ihtiyacını duyduğu gün kimseden nasihat almadan kendisine yol gösterebilecek| selâhiyetli bir adama danışmayı da ihmal etmez.

- Bu klâsik kaidenin (Hukukî meselinin) sıkı taraftarları; bu prensibin doğrulư̆unu isbat ettikten sonra, şimdi de ondan ç- 
kacak neticelerinde makul ve umumiyetle mahkeme içtihatlarına uygun oldư̧unu, göstereceð̧iz diye sözlerine devam ederler.

A - lik olarak-bu müttefikan kabul olunur-ceza mahkemelerinde suçlu; kanunu bilmediğini veya kanunu yanlış yorumladığın isbat ederek cezadan kurtulamaz, boş yere bu bilgisizliğinin meşru olduğunu (excusable) veya bu yorumunun bir dereceye kadar makul olduğunu iddia edecek, bos yere kanunu kendisi gibi anlamış olan yazarlan ve mahkeme kararların gösterecektir. Hüsnüniyeti ne kadar aşikâr olsada üstünlük yine kanunda kalmalıdır [1].

B - Kanunu bilmemek yalnız suçu ortadan kaldırmamakla kalmaz, prensiplerin sertliłi, bunun cezayı azatıcı sebep olarak kabulüne de mani teşkil eder. Fakat doğruyu söylemek lâzım gelirse, Jüri kararlarında mucip sebepler göstermediğinden, onun, prensipleri ihlâl etmesine mani olunamadıł̆ı gibi bir yargıç cünha (Police correstionelle) veya kabahat işlerinde *cezayı azaltıcı sebeplerin mevcudiyetine binaen> demekle iktifa ederse [2] verdiği karar tenkide maruz kalmaz. Fakat ekseriyetle yapıldıø̆ı gibi yargıç, cezayı azaltıcı sebep olarak kabul ettiği vak'aları tasrih eder, ve eyger bunlar arasında kanuni hatada mevcut olursa karar sırf bu sebeple islâha veya bozulmaya elverişli olur.

C - Şimdi de geniş Hưsusî hukuk alanına girelim, orada da ayni prensibe tesadüf edeceğiz. Sade bir sbilmiyordum demekle kanunun uygunlanmasından kurtulunulamaz, çữnkü bilmek lâzımdır. Bir kanunun tayin ettiği hak düşümü, zaman aşımı, butlan veya herhangi bir ceza hakkında ki hükümlere uygun. hareket etmeyen kimse, bu bilgisizliğini bahane ederek bunların tatbikinin önüne geçemez. [3]

[1] Cf, Ulpien: «Igoorantıa enim excusaturnon Juris, sed facti. L. II, fr, 4, de is notantur infami. Bir sok yabanel kanunlar, earih olarak hukukta hatanin veya hukukî bir kaidenin bilinmemesinin bir suçu mazur gösteremiyeceğgini kabul ederjer: Macar Ceza Kanueu (Pr. 81 ve 82), Avusturya Kanunu (Paragraf 3) Italyan Kanuna (Mad. 44) Danimarka Kanunu (Parag. 42) Portekiz Kanunu (Mad. 29), - Adde, cuss. 17/Temmuz/1899, s. 89.1.718, 28/Haziran/1864, D. 62.1.305, - Orleéan, 22/Nisan/1868, D. 63.2.88-Cass. 12/A gustos 1881, S. 85.2.80 8/Eylül/1892, D. 98.1.858. - Touluose 17/Eylülí1884, S. 85.2.80, - Lyon. 4/Ocak/ 1884, D. 84.22.159. Garraud, droit péroit pénal francis, 2 ed. t. L. P. 596 , Laine, Traité elem. de droit erimnel,

[2] Yargıcın meveudiyetini kabul etiiği cezayı azaltıcı sebepleri tasrih etmek zoranda olmadı̆̆ı malumdur. (Cf. Garraud. op, est. t. J. p. 556).

[8] Aubrye Rau 5 ed., t. 1. p. 94, Laurent nede bakiniz. t. 1. p. 23 ve 24. 
D - Kanunu bilmemek; yalnı doğrudan doğruya kanunun size tatbikine mani olmayacağı gibi, kanunî bir vecibeyi yerine getirmeyi ihmalden doğan sorumluluğu da ortadan kaldıramaz. [1] Meselâ: İs hukukuna dair olan nizamları ihlâl eden bir işveren hüsnüniyetle hareket etmiş olsa bile işçilerinin bundan doğan zarar ve ziyanların tazminle mükelleftir.

E - Hatta daha jleriye bile gitmek lâzımdır. Hukuk kaidelerinin bilinmemesi, bunları ihlâl edenin kusurunu ortadan kaldırmadığı gibi hatta bu kusuru hafifletemez de. Hukuk mahkemeleri; bilindiği üzere bir çok hallerde kusurun derecesini ölçmeye mecburdurlar. (Meselâ : Culpa lata neticelerine karşıı, yapılan sigorta kanuna aykırndır, Medenî Kanunun 804 1378, 1927, 1928, 1992 inci maddeleri gibi bir çok kanun metinleri bazı kimselerin sorumluluxların, kusurlarını ağırlık derecesine göre tayin ederler, $9 / \mathrm{Ni}$ san/1898 tarihli kanunun 20 inci maddesi de böyledir v.s...) Fakat madem ki, herkes kanunu bilmeye mecburdur, filiyatta onu bilmemenin veya bilmemenin bir önemi yoktur. Ona, muhalif hareket her zaman aynı şekilde ağırdır.

F - Nihayet son olarakta, kanuna aykırı hareketiniz bir üçüncü şahsm tesiri altında işlenmiş ise, bunun neticelerinden siz scrumlu olmakla beraber; hiç olmazsa sizi aldatan bu üçüncü kişiden tazminat isteyemez misiniz? Hayır, çürnkü insan hukukî bir meselede iğfal edilmeye müsaade etmek suretiyle bizzat kendisi; başına gelen bu muvaffakiyetsizliğin failidir. Günkü insan; kendisi hatta ettiği içindir ki, başkası tarafından aldatılmıştır. Burada, bazı kimseler işte bu kaidenin drakonniyen (draçonnien) bir tarzda tatbiki diyebilirler. Lâkin bu uygulama şeklini müdafaa için yargıtayın çok defalar münakaşa edilmiş bir içtihadı ileri sürülür. Tren memurları, tarifeler hakkında vermiş olduklałı yanlış malûmatla sizi bir zarara soktukları zaman, onlardan tazminat istemek hakkınız varmıdır? Bu husus da misâl mahiyetinde olmak üzere yargıtayın bir kararın zikredelim: Tren nakliyat tarifeleri, kanun kuvvetinde olup neşr ve ilân edilmiş olan bạkanlık kararile tesbit edilmiş olduğundan, değiş̧tirilemez ve bunları bilmemekte bir özür sayılmaz. Binaenaleyh davacı bu nakliylat şartları hakkında bir memurun verdił̣̆i malûmatla hataya sevkedilmiş olduğunu kanunen iddia edemez, bundan dolayı temyiz edilmiş kararda haksız

[1] Aubry ve Rau. ibid. 
olarak bu hata ve gecikmenin neticelerinden doğan zarar kum* panyaya yükletilmiștir... vd. [1]

Yüksek mahkeme diğer mahkemelerin uzun bir mukavemetine rağmen, aşă̆ı yukarı bütün yazarlarında tam bir tasvibile her zaman bu ictihadını muhafaza etmiştir. [2]

Halbuki böyle bir hal tarzı şu genel prensibin vücüdünü icabettirir: Sizi bir hukuki hata yapmağa sevkeden veya böyle bir hata yapmaniza müsamaha eden kimseden tazminat istenemez.

Hatta biz daha ileriye giderek diyelim ki, madem ki bu prensip göstermiş olduğumuz - bu özel vaziyte tatbik edilmektedir, o halde sair hallerde de evveliyetle (a fortiori) uygulanmahdur.

Hakikaten tren tarifelerini ayniyle, kanunlarda oldư̆u gibi resmî bir neșr ve ilân tarżı yoktur. Dił̌er taraftan bu tarifelerin resmî metninin tek malikỉ kumpanyalarda bu tarifelerin serbestçe halk tarafından görülmesine müssade etmezler. [3]

[1] Cass. civ. 21/Oeak/1901 Gaz. des. trib. 6/Haziran/1801

[4] Orléan ticaret mahkemesinin bir kararın bozan 13/2/1868 tarihli yargltay kararı (Lamme-Fleuxy, code annoté de chemin de fer, 1905, p. 891) Saint paul tiearet inehkemesinin bir kararin bozan $16 / \mathrm{Mart} / 1869$ tarihli yargitay kararn (ibid) Sein ticaret mahkemesinin bir kararın bozan 15/Aralık/1874 tarihli yargitay karar1; Csss. req 15/Haziran/1875, s 77.111 .76 kararı bozulan mahkemenin ismi gösterilmiştir.

[3] Hakikaten tarifelerin halkın tam güvenlikle dayanabileceł̆i ve icabında kumpanyalara karşı derineyan edebileceğj bir yayrulama tarzlan yoktur. Bununla beraber kumpanyalar gönderenlere kabul edilmis ola o tarifenin önemli noktalarını gösteren bir makbuz (recepice) vermek zorudadirlar, bu hususun hatal yapilmıs olması kumpanyalara yalnız cezai sorumluluk yükler. (Cass. crim., 31/Temmuz/1857 Bull. Cass. crimm. 295) Hukukî sorumluluk asla Cass. 1/Mart/1095 gaz des. Trib, 19/Nisan/1905; diğer taraftan 15/Kasım/1846 tarihli (Ordonence) 48 inci maddesine tevfikan yapılan ilâılarda remî bir ilân mahiyetini haiz deģildir. Bu ilân kısmen afị̧ ve kısımen de gariara asılmış el tarifesi (ehaix kitap evinin neşrettikleri gibi) șeklin te yapılır. Yargıtayda (ch. civ.) bu el tarifelerinin *hiç bir resmî karakteri» olmadıł̆ına karar vermiştir, 26/Hazjran/1893 Nammé - fleury, code annté de :ehemin de fer P. 125.124) Afişlerde aynı şekilde Chaix kitapevi tarafiadan bazırianmış olup onlar da resmî bir karakter tanımak için bị bir sabep yoktur. Nihayet 7/Ocak / 898 tarihli bir bakanlık sirküleri tarifelerinde resmî ga-

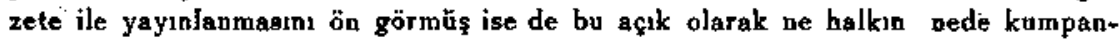
yaların birbirlerine karşı olan haklarından, ve ne de kumpanyaların mesuliyetlerinded hį̧ bir sey deģig̨tirmemiątir: Bu yayımın ancak resmî bjr bilgi vermekten baģka bir kıymeti yoktur, Bütün bu noktalar hakkında daha fazla malûmat için tarifelerin hukukî mahiyeti hakkındaki etüdümüze bak, 136 vd, (Rousseau, 1906) 
Buna rağmen eğer kanunu bilmemek özür saylmaz kaidesi (hukuk meseli) kumpanyalar lehine tarifelere uygtunlanmakta devam edilirse, bunun halk menfaatine olarak kanunlar hakkında da uygunlanması ne kadar çok daha yerinde olur.

Metheme kararlarının bize ilhâm etmiş olduğu misallerden birini ‘rösterelim: Elinde işletilecek sermayesi bulunan bir şahıs, bir komisyoncuyu, bu parayı işletecek bir vasıta bulmaya mernur eder, komisyoncu müşterisine bir evli kadın tarafından kocasının muvafakati alınmadan imzalanmış bir senedi; böyle bir senede kanunun ne kadar az bir değer atfettiği hususunda müșterisini ikaz etmeden verir. [1]

Borç ödemediği tardirde komisyoncunun sorumluluğu cihetine gidilmelidir? Montpellier mahkemesi, bu soruya müsbet cevap verdi. Fakat bu iş yargitaydan geçmiş olsaydı, bunun aksi bir karar vereceği düşünülebilirdi. Çünkü hakikaten neden bir komisyoncu, bilinmesi kolay olan kanunlar hakkında müş̧erilerine resmî metni yalnz kendilerinde bulunan kumpanyalarinn; bu tarifeler hakkında kendi müşterilerine vermek zorunda oldukları bilgiden daha fe:zlasını vermeye mecbur tutulsun? Bu bakımdan burada da dið̌gerinde olduğu gibi halkın itiaazlarına karşı ๖Kanunu bilmemek mazaret sayılmaz., diye cevap vermek lâzımdır.

G - Bu genel kaidenin müdafileri sgörüldüğł üzere bu kaide harfiyen nazara ahnabilir, ve bunu tadil eden bir metne tesadüf edilmedikçe her zaman uygulanabilir» diye sọ̆zlerine devam ederler.

Lâlin burada: Elbette hususî hukúkta istisnalăr pek çoktur. Kaideler haline girende yine bunlardir ve kaide de ancak istisnaen tatbik edilir diyerek sözümüzü keserler, ve misâl olarakta bize Medenî Kanunun 201 inci maddsini ayn zamanda 459 uncu maddesini, 11109,1110 uncu maddelerini ve 1299 (in fine) ve 1376-1377 inci maddelerini, 2265 ve 2279 uncu maddelerini ve diğer bir çok maddelerini göeterirler. Filhakika bu kadar metin bolluğu altında, bir çok nesiller tarafından tekrar edilmiş olan bu ihtiyar kaidenin boğularak ortadan kalkması lâzım geldiği doğru gibi görünür.

Fakat onun taraftarları; müsterih olalım diye tekrar sôze başlarlar, ve bütün bu metinler bir şahsın bir hata işlemiş oldugunu kabul ederler, fakat bu hatanın nevini tasrih etmezler. Bu

[1] Cpr. Montpellier 21/Aralık/1889, Fr. 90.2,250 
metinler fïli hatalara uygunlandı̆̆ına göre hukukî hatalara tatbik edilemezler, zaten medeni kanun daha başında herkesi kanunu bilir farz eder. Başka bir deyimle hukukî hata yok addolunur. Kanun yapici bir kere bu prensibi konduktan sonra, kanunu yorumlayacak olanın bunu her vakit için göz önünde tutacağını düşünerek daima bunu tekrarlamayı lüzümsüz bulur; derler. .

Gerçekten kanuna bilmemek gibi özürü olan bir şahsın, kendilerine hiç bir kusur atfedilemiyecek kimselerle menfaat ihtilâfına düşmesi halinde bu kişiye; âdil bir kaide olan «Jura vigilantibus prusunt *un uygulanmasım icabettirmez mi? Bu görüș tarzının öyle büyük bir kıymeti vardır ki, doktorinin bu an'anevi kaideyi ima edilen hallerde değerden düşürmesine rağmen, mahkemeler bunun tesiri altinda kalarak israria onu tatbikte devam etmişlerdir. Bu bakımdan, evvelâ yüksek mahkemenin de (ch. de req.. 14/Ağustos/1882) aşă̆ıda görülecek şartlar altında vermiş oldựu karara işaret edelim:

Karaya oturan bir vapurun kaptanı; müekkillerine müracaat etmeden geminin yükünü, kurtarılması mümkün olduğu ve satışında da aceleye lürzum olmadığı halde müstacelen sattırmıştır. Satın alan hüsnüniyetine dayanarak bu satışın sahi bir satıs oldươunu iddia etti. Davaya bakan yargıçlar kendisini haksız çıardilarsa da yargıtay diğer bozma sebeplerinin yerinde olmadığını söyledikten sonra: «Müşteri Simon her ne kadar hüsnüniyetli olduğunu ileri sürerek malların bu satıșının hiç olmazsa kendisi için hüküm ifade edecȩ̌ini iddia etmişse de; bu iddia temiz edilen kararda kanunu bilmemek bir mazeret saylmaz mucip sebebiyle reddedilmiştir, ve bu da yerindedir. Çünkü hukukî hatayı, ileri sŭrerek medenî hukukta meselâ 20 ve 10 senelik bir zaman aşımı veya 2279 uncu maddedekj kaide gibi haddinden fazla bir menfaat temin edilemez.?

Sarih olan şudur ki: Yargitay bu kaideyi. (Hukuk meselini) hatta yüksek bir takım yazarların tatbikine kuvvetle muhalif oldukları Medenî Kanunun 2265 ve 2279 uncu maddelerinde bile istimâl etmektedir. [1]

Medenî Kanunun 549 cncu maddesinin öngördüzüü önemlì bir

[1] Bu kaidenin uzgulapmass lehinde: Troplong 11, 926, Lurantod XXII 388. Bilhassa 31 pr. Dlgde usurpet usue, $(41,3) \cdot 15 \mathrm{dig}$, pro. eim $(41,4)$ Kanuna istinat ederler, 
vaziyeli de göz önünde tutalım. Başka bir yargıtay kararından şunları okuyoruz :

(ch. des. req) - 549 uncu madde mucibince tabii semereler iyi niy atli zilyedin olur. 550 inci maddedeki tarif mucibince, zilyet malik sıfatiyle ve sakatlı̆̆ını (vice) bilmediłi bir hukukî tasarrufla temellük etmiş ise iyi niyetlidir. Bu sakatlı̆̆ın (noksanlığın); bir kamu sanununu ihlâl eder mahiyette bulunması hali bundan müstesnadır. Zilyedin hatasının fiili veya hukukî bir sebepten doğmuş olmasmin önemi yoktur [2].

Bu kararda; görüldüğü üzere etüdümüzün başında, kamu kanunlariyle diğer kanunlar arasında yaptığımız ayırmayı teyit eder. Herkes bu kaidenin çürütülmesi mümkün olmayan bir karine olarak kabulü halinde, bunu, fertlerin yapacaklan sözleșmelerle hükmüden kurtulmaları mümkün olan kanunları istihdaf etmediğini bilir. Fakat kamu intizamına taallûk eden kanunlarda, yukarıda işaret edilen karardanda anlașılacă̛̆ı üzere skanunları bilmemek maazeret saylimaz.»

Bununla beraber mahkeme içtihatlannın doktrịn ile birleşerek bu kaideyi (meseli) tatbikten kaçındıkları çok mühim bir hal vardır. Bu da Medenî Kanunun 1109 ve 1110 uncu maddelerinin öngördüğ̈̈ haldir. Yazılara ve birçok mahkeme pararlarına inanmak lâzım gelirse, bütün muvakaveleler ve daha genel olarak bütün hukukí muameleler iki nevi hata arasında hiç bir fark gözetilmeden, hatta hukukî bir hata dolayisiyle de iptal olunabilirler. [3]

Meselâ at satışlarında; bu satış dolayısiyle ister kanunun en genel kaidelerinde hata edilsin, ister bu hata siatışa arzedilen atın binek hayvanı olup olmadıŏında yapılsın, ikiside tamamile aynı önemi haiz olacaktır. Bu kaidenin (hukuk meselinin) zecrî (radič.l) taraftarları; lâkin bu yukanda işaret edilen teori birçok itirazlara müsaittir. Zaten mahkemelerde bunu hiç tereddütsüz uygulıımaz. Acaba bu nazariye neye istinat ettiriliyor? Kanun metinlerine mi? Fakat onlar yalnız şeyin mahiyetindeki hata ile

[2] Rep. 11/Ocak/1887, D, 88.5.269

[8] ef. Demolombe, $t$ XXIV: 129 - Aubry et Rau, $t$ : 1 (5 ed,) p. $496,-$ Laurent t. XV. 505,508 - Baudry Lacantínerie et Barde, t. 1, 70, - Planiol, t. 1 (2 ed.) 280 - Metz, 28/Kasim/1817, s. 19.2142, - Touluse, 16/Ocak/1824-24, 2. 115 Besançon, 1/Mart/182, D. Rep. Obligation, n. 147 - Grenoble, 24/Tem. muz/1830 S. 31-2-36, - Limoge, 8/Aralık/1887, s. 89.2.27 Cass. Civ, 12/Mart/1845 S. 45-1-525, - Cass. Req. 26/Mart/1888, S. 89, 1, 2.48- Chambery, 11/Ocak/1894 D. 95.2285 
şahıstaki hatadan bahsederler, genel bir kaide olan kanun nasl olurda bir şeyin mahiyetinden ve insandan bir parça teșkil eder.

Mantıga mı istinat ediliyor? Hele bu asla olamaz. Nasıl olurda biri yaptı̆̆ını bilen, diğeri hafiflikle kanun hakkında bilgi edinmeden sözleşme yapan iki şahıstan birinin bu bilgisizliği yũzünden mukavele feshedilir. Bilgisiz ve hoppameşrep âkidi zarara sokmamak maksadiyle bilgili ve dikkath hareket edeni zararlandırmak! Düşüncesiz hareket edenlerin iradesini her şeye üstün tutan tuhaf bir adalet olurdu, bu doğrusu diye șiddetle itiraz ederler.

Mahkeme kararlarım daha yakından takip edelim:

Hukukî hata ile muallel bulunan bir hukukî muameleyi sahih olarak kabul etmesine rałmen yarğıtayca bozulmamış iki istinaf mahkemesi kararına (Besançon ve Dijon) tesadüf edeceğiz. [1]

Her ne kadar Besançon mahkemesi zahiren carî olan bu nazariye ile ahenk halinde kalmał̆a gayret etmişse de hakikatte onu 1382 inci maddeyi buraya karıştırmak suretiyle değiştirmiştir. [2]

Meydandadır ki, bu karar sayesinde yalnız medenî kanunun 1109 ve 1110 uncu maddelerinin uygulanmasından de gril fakat kanunun sözleşmelere dair olan bütün hükümlerinin tatbikinden kaçınılmak lâzım gelecektír. Fakat şu da aşikârdır ki bu tarzı hareket, kanunu tatbik değil tadildir. Acaba ne için Besançon Mahkemesi; burada sözîeşmelerdeki hatalar hakkında cari olan nazariyenin, tatbikinden kaçınmak istedi? Çünki bu nazariye ile bariz bir adaletsizlik içine düşeceğini görüyordu. $O$; doğru bir hal tarzına yanlış bir gerekçe gösterdi. Fakat neden? Çünki, sözleşmelerdeki hata alnından an'anevi kaideyi bertaraf eden teorinin bazı kısımlarını muhafaza etmek istedi de ondan. Eğer bunun aksine olarak sadece kanunlarımıza hâkim olan k kanunu bilmemek mazeret sayılmaz» büyük prensibinden dolayı bir hukukî muamele feshedilmez demiş olsaydı verdiği karar her bakımdan tasvibe şayan olacaktı.

[1] Besançon, 1/Mart/1864, D. 64.2.61; Dijon. 27/Temmuz/1870 D. 71-2-268

[2] Dallozun bir notu bu karardaki görūş tarżnt şôyie bülâsa eder:

*Prensip olarak hukukî hata... Fiili hata gibi riyazi ve dolayısiyle vecibeyi ełger bu hata rızanın tek ve hakiki saiki ise; hatta üçüncü sahıslara karø̧ bile ifsat eder, lâkin bu hatanı makuI sebeplero dayanması Jâzımdır. Fakat eğer adi ve kaçıolması kolay bir hata bahis mevzuu ise bunu ileri süren âkidin Besançon mahkemesînin de Kabul etmiş olduğu gibi aydm ve bilgili bir müşavire de danışmayı ihmal etmesinin neticelerine katianması lâzım gelir. Exer bu tedbirsizlił̧i ile 
Bu kaidenin müdafileri; esasen bu kaidede diğer bütün kaideler gibi bazı tadillere müsaittir, fakat bunlar ancak kanun koyucunun çok açı ve sahih olarak müsaade ettiği yerlerde yapılmalıdır; yani adetleri pek az ye önemli olmiyan hallerde [1] sair dịgrex bütün hallerde bu kaide uygulanmalı ve hukukî hata mevcut değil addolunmalıdır, derler ve ilâve ederler:

Görüilüyor ki bu suretle vasıl olduğumuz hal çareleri, umumiyetle en adil olanlaridir. Bazı vaziyetlerde bunlar biraz sert görünseler bile bu eski kaidenin, önüne geçilemiyecek içtimaî zaru* retle dayandığı unutulmamalı, ve bu hakikat iyice anlaşılmalıdır ki bazı karanık ve meçhul hislere ve hatta mübalâğalı hassasiyete kamunun açik menfaatı feda edilmesin.

Kanun bilmemek özür sayılmaz kaidesi (Hukuku meseli) lehine söylenecek sözler aşağı yukarı bunlardan ibarettir. Fakat bu deliller hakikaten ikna edicimidirler ? Inceleyeceğimiz işte bunlardır.

Görüldüğü üzere izah ettiğimiz nazariye esas itibarile hukukî hata ile fiilî hata arasında büyük bir uçurum açmaya çalış̧r. Fïlî hata, mevcut ve bu sebeble hukukî neticeler doğurmaya müsait aćdolunur. Bunun aksine olarak hukukî hata, temamen gayri mevcut farzolunur. - O sanki hiç yok gibidir - Halbuki bize göre, bu ikilik yanlş̦tır. Hukukî hatada fiilî hatanın tabi olduơgu genel prensiplere tabi otmalıdır. Çünkü hukukî hatada fiilî hata gibi

üçiincü sahısları bir zarara sokmus (onlarn aldatmış ise) ba takdirde medenî huku. prensipleri mueibioce madd (1382 ve 1383) tazmini lâzın gelen ağır bir kusur işlemiş telâkki olunur. Hatadan doğan zararı tazmin mecburıyeti, üçüncä şahıslar lehine. bunun reticesinde bir istirdat davası açlamayacağ hakkıada bir bir teminat def'inin mevcudiyeti halinde temlik edilen gayrî menkulün iadesini talebede hak vermez.» Bahseyledił̧imiz kararın özü hülâsatan iște budur. Bu hadise de i̧̧lenmiş olan hata, bu derece fahiş miydi ki bôyle sert bir muameleye tabi tutmak mecburiyetinde kalınmıştı? Bu hata, bir mírasçının temsil selâhiyetinin ejvar kısımlarına kadar samil olmıacay kaidesinin bilinmemecinden dolayı yaplinıştı. Ne kadar az kimsd böyle bir hataya düşmemis olmakla övünebilir.

[1] 5/Kasm/I870 tarihli kararnamenín 4 üncü maddesi kanun ve nizamlara karşı gelenier tarafından, mahkemelere veya jesbı haılinde idarî veya askerî makamlara ileri sürülecex olan kanunu bilmemek def'inin; bu nizam ve kaidelere muhalif hareketin kanuuun yaylmasından itibarea ų̈ gün içinde işlenmiş olması halinde kabui edileceğini ön görür. 9/Aralık!1814 tarihłi Nizamname gereğince (Mad. 27) Octruva resmi harkındaki bükümlerin, octruva dajrelerinin iȩine ve disurıa asılmast lâzım geldił̧ine de işaret edelin. Mahkemo içtibatları; böyle ilânların mevcut olmaması halin le bo hükümlere karß̧ gelenlerin| cezalandırılmayacağı sonueuna varmiştır. Cass. $23 / \mathrm{Kas}$ m/1895 S. 98.1.1.77.

Toulouse, 30/Mart/1896, 1903, Gaz. Des. trib, 19/Mart/1905. Mamafih buna bune muhalif olan Paris 4/Haziran/188, S. 81.2 .142 bakı 
hakikî bir varlık olup bir hiçlik, yoklukmuş gibi telâkki edilmimeyecek bir şeydir.

Bizce nasıl ki herkesin bütün maddî vak'aları bilir addi doğru değilse, aynı şekilde herkesin bütün kanunları bilir addedilmesi de doğru olamaz. Tabiidir ki, tıpkı maddî vak'alarda olduŏu gibi kanunlar hakkında bilgisizlik bu kanunların nizamlarındaki hadjselere uygulanmalarına mani teşkil edemez, fakat bunu izah için hukuk içine garip bir fiction sokmağa da lüzum yoktur. Cemiyetin selâmetinin (salut) faydasız tasavvurlarla, istenerek yapılan ha* yallcre istinat etmesine de lüzum yoktur. Biz sosyetenin menfaatine, her hangi bir kimse kadar riayet gösterdiğimizden dolayidır ki onu hakikaten hürmete şayan bir temele, gerçekliğe, dayatmak istiyoruz.

İşte bu görüș tarzından hareketlerdir ki biz an'anevi kaidenin (Hukuk meselinin) tenkidini yapacăgız. Hakikatı söylemek lâzım gelirse bu kaideyi müdafaa için eskiliğinin delil olarak ileri sürülmesi, bu kaidenin kesin bir surette red edilmesi için kâfi değildir.

Yüzyıllar geçerken, her şeyi yavaş yavaş yıpratırlar, eski binaları, eski adetleri, eski prensipleri. Elbette ki geçmișe hürmet takdir edilecek bir karakterdir. Fakat ilerleme aşkıda hiç şüphesiz ki hakir görülecek şeylerden değildir. İşte bunun içindir ki, yeni bir teoriyi red etmeden evvel, onun iyice ta içine kadar girmek lâzımdır. Kanun metinleri bakımından tenkit ettiğimiz görüş tarzl, medenî kanunun 1 inci maddesinin iki ve üçüncü fıkralarına dayanır. Lâkin Kanun koyucu; bu madde ile sadece eskiden ve bilhassa Roma hukukunda; küçükler, evli kadınlar askerler ve gaipler hakkında mevcut olan bazı imtiyazlardan uzaklaşmak gayesini gütmęk istemiştir. [1]

Bu gün hiç bir kimse bilgisizliłgini ileri sürerek kanunun pençesinden kurtulamaz, fikrimizce medenî kanunun birinci maddesinin bütün mânası iş̧te budur. Fazla olarak bu metin sonradan neşredilen ve bütün bu meseleyi yeniden tanzim eden kanun ve kararnamelerle zımn olarak deł̧iştirilmiştir. Bizce; halen yalnız Pariste kanun ve kararnameler neşr ve ilân edildiklerinden bir gün sonra, diğer bũtün arrondismanlarda bu kanun metnini havi resmî gazetenin bu arrondismanın merkezine vasıl olduğundan bir gün sonra tatbiki mecburidir, diyen $3 / \mathrm{Kasim} / 1880$ tarihli kanunun ikinci

[1] Savigny, System des heutigen Roemisehen rechts, t. III.p.429 vd. 
maddesi göz önünde tutulmalıdır. Bu kanunda, görüldü̆ğü üzere artık hiç bir fictiona baş vurulmamıştır. $O$, sadece kanunların göstìrdiğ̆i müddetlerden sonra herkes için mecburî olacăğı sôyler. Bizd , bu förmüle hiç bir ilâve yapılmadan oldư̆u gibi uygulanmasinn istemekle iktifa ediyoruz. Şimdi de mantık zaviyesinden düşünelim: Bize hakikatte herkes kanunu bilmez, halbuki kanunun herkese uygulanması lâzımdır. $O$ halde herkes onu bilir addedilmelidir diyorlar. Fakat acaba bu neticeye varmak zorundayımıyı? Biz rekrardan bu muhakerne tarzını ele alahım ve bize daha doğru görünen bir mantıkla diyelim ki: Herkes kanunu bilmez, halbuki onun herkese uygulanması lâzımdır, o halde kanunun hatta onu bilmeyenlere bile tatbiki lâzımdır. Bu neticeye; neden onu tehlikeli yollara seykedebileceğini birazdan göreceğimiz parazit bir sanı (fiction) aşlamalı. Fakat belki de kanunun hatta onu bilmeyenlere de tatbikinin mecburî oluşunda biraz sert olan bir şey vardır, denebilir. Filhakika kanunun, yalnzz ondan haberdar olanlara uygulanması temenni edilebilirdi.

Işte Hukuk âlimleri mümkün oldư̆u kadar vicdanin bu arzusunu (desiratum du consience) göz önünde tutarak herkese az çok farazi bir hukukî bilgi atfetmişlerdir. Herkesin kanunu bilir addolunmasından dolayıdır ki onun size de tatbiki doğru olur. Biz; elbette ki ima edilmek istenen «Desiratum du consiencesi biliyor ve hararetle kamu makamları tarafından kanunun genis bir surette yayınlanmasım sağlamak için alınan tedbirleri yerinde buluyoruz, diye cevap veriyoruz. Lâkin bir kimse bilmediği bir kanunun (Kaidenin) tatbikinden bir zarar görse bu zararn, ona, kanunu bilir addolunduğunu söylemek suretile azalttığımızı ms zannediyoruz. Ve ona bu suretle temin etmek istediğimiz tesellide bir hayalden ibaret olmaz $\mathrm{ml}$ ?

Nihayet bize bununla beraber hukuk hakkındaki bilgisizliği adi bir vak'a hakkındaki bilgisizliğe veya hukukî hatayı fiili bir hataya benzetemeyiz. Çünkü iyi bir vatandaş, kendini idare eden bütün kanunları ahlak ve hukuk bakımından ögrenmeye gayret eimek zorundadır, halbuki bunun aksine olarak memleketde olup biten bütün olayları ögrenmeğe mecbur edilemez. Bunun içindir ki fiili hata değil, fakat hukukî hata bir kusurdur, hiç bir kimsede kendi kusurundan istifade edemiyecekinden, tabidirki yargıç önündede kendi lehihe olarak hukukî hataları değ̛il ancak fiili hataları ileri sürebilir; diyorlar. Bizde iyi bir vatandaşin hukukan ve ah- 
lâkan bütün kanunlan bilmeye mecbur oldư̛̆ doğru deł̧ildir. Bunun böyle oldư̛̆unu kabul halinde ne olacaktır? Herhangi bir şekilde memleketimizde bir delilik rüzgârının herkesi bütün kanunları noksansız olarak öğrenmeğe sevk ettiğini bir tasavvur ediniz: Tarlalar, fabrikalar, mă̆gazalar boşalacak, milletin bütün hayatı hukuk fakültelerinde, mahkemelerde toplanacak. O zaman ekmeğimizi kim yapacak, kim bize elbiselerimizi, evlerimizi hazırlayacak? Memleketimizin Intellektuel mamelekini edebiyat, güzel sanatlar ve fizikî filimler alaninda kim muhafaza edecek? Herkesin; hukuk bilmesi lâzım geldiğine kani olduğu gün, hiç şüphe yoktur ki bütün sosyal hayat duracaktır; diye cevap veriyoruz. Lâkin bize herkes yalnız kendine uygunlanması mümkün kanunları ögrenmelidir diyorlar. Fakat bizde bir kanunu, incelemeden evvel bunun bir gün bize tatbiki mümkün olup olmadiğını nasıl anlayabiliriz diyoruz. Zaten bu günkü mevkimizin ne olduğgnu bilebilsek bile yarının ne olacağını nasıl kestirebiliriz? Bir tesadüf, bir proleteri birçok hukuk kaidelerine tabi bir rantiye mevkiine sokabilir. Insanlar!; hukukta kendilerini ilgilendiren şeyleri ögrenmeye mecbur etmek, onları bütün hukuku bilmeye zorlamak demektir. Herkes bu hususta selâhiyetli kimselerden, izahat almalıdır, denebilinirse de, bu şahıslara kim, ne sormaları lâzım geldiÆ̆ini ögretecektir? Hakikaten iyi bir vatandaş, etrafında geçen hâdiselere temamiyle bigâne kalamayacağı gibi, elbette ki kanunlarıda tamamen bilmemezlik edemez, lâkin basit bir förmül ile apriori olarak onun gerek hukukî alanda gerekse maddî sahada öğrenmeye mecbur olduğu bilgilerin sınırını çizmek mümkün değildir. Bilinmemeleri kat'iyen mahzur görülmeyecek yeni kanunlar (Meselâ askerlik kanunu veya doğrudan doğruya ahlâka ilgili hukuk kaideleri) vardır. Tıpkı maddî alanda da, bir silâhın tetiğine dokunulmadan evvel onu dolu olup olmadığının, bir kâğıt imzalanırken içindeki yazıların bilinmesi lâzım geldiği gibi.

Kısaca maddî (filî) vak'alarda olduğu gibi hukuk alanında da herşey bilinmeyebilir, fakat hiç bir şey hakkında bilgi sahibi olmamaya da müsaade edilmez. [1]

[1] Belkide bize şöyle bir itiraz yaplabilir : Cezai sorumluluk bir kusuru (kasdî) icap ettirir, o halde hiọ bir kusura müstenit olmaksızın az kullantan veya mevcudivetlerinin bilinmesi iẹin ahlak kaidelerinin kâfi gelmediği bir cok kanunlar, bu suretle çok vakit bilinmemeleri yüzünden tatbik edilemiyecektir. Cünkü bilinmeyen ve bilinmemesi de hakh olan cir hukuk kaidesini ihlâl bir kusur teşkil etıez. Biz ayn müş̧ül durum, 
Bu sebeple bizce, herkesin kanun bildiğinin kabul ile hukukî̀ ha:a ile fiili hata arasinda derin ayrılkklar meydana getirmeğe hiç bir sebep yoktur. [1]

Biz, bu görüş tarzından hareketle mevzuu bahis kaideden sözde çıkarıldığı ileri sürülen sonuçları inceleyeceğiz. Bunlardan bazlları bizatihi kabul edilebilir olmakla beraber ileride görülebileceği üzere başka şekilde de yorumlanabilir. Lş̧te bu sonuçların çoğu bize, lüzumsuz bir sertlikte ve haksız görünüyor. Biz; nazariyemizin, bu sertlikten uzaklaşmayı mümkün kslmasından dolayı bahtiyariz.

A: Evvela bize, ceza hukukunda hukukî hata ile fili hata arasinda esash bir fark bulunduğu, hukukî hatanın cezayı ortádan kaldıramayacağı gibi hatta onu azaltmayacă̆ı; (Hırsızın veya kalpazanın ihlâl ettiği kanun hakkında bilgi sahibi olup olmamasunın önemi yoktur) fiil hatanın ise bunun aksine olarak bazı hallerde suçlunun beratını bile (hakikaten vestiyerden yanlışlıkla kendi paltosu yerine bir başkasınınkini alan kimse cezalandırılamaz mümkün kıldığı ileri sürülür. Fakat biz bazı hallerde hukukî hata dahi suçiunun beratını sağlar diye cevap veriyoruz:

Meselâ, Bir tarlada çalş̧an bir amele bir define buluyor ve yanlıṣ olarak bunun $2 / 3$ ünün kendisine ait olacağının zannederek tarla sahibine definenin $1 / 3$ ünü (yarısı yerine) vermeğe razı oluyor. lyi niyeti bu ameleye, hile ile başkasının malından bir-kısmınıçalmak suçunu isnat etmeł̆e ve onu hrrsızlıktan mahkûm etmeğe mani olur. Hakikaten ister bir hukukî kaide de, ister basit fiilî (maddî) bir vak'a üzerinde hata edilsin ugulanacak prensip her zaman için aynıdır: Bu hata suçun esash unsurlarından birinin ortadan kalkmasını mı mucib olmuştur? Bu takdirde ne suç nede ona tatbik edilecek ceza vardır. Hata, bunun aksine olarak suçun

hukukî hata yerine, fiilı̂̀ hatamın nazara alınmasiylede meydana ộkar diye cevap veriyoruz. inobstreto olarak inêlenen ve hukukî bir kusur teşlkil etıneyen fịilî bir hata bazen bizi bir nizamı (hukukî kaideyi) ihlàl tehlikesi karşıında bırakabilir. Bu da tıpk1 hukuk alanmola yapılumş bir hała gibi eezayı mueibtir. Hakikat şuđur ki, bir cezaya maruz kalmak ị̣in bir kanunun ihlallinin size ał́f kàfidir.

[1] Söylemeye lüzum yoktur ki, biz bu görüş tarzmmzlada zaten az ic önemli ve kanun metinlerinden ộkan bazı istisnaları kabul ediyoruz. (Cf. Mad. 336 ve 2050) zaten işaret ettiğimiz bu metinter doktrin tarafından umumiyetle tenkit edilerek değiştirilmesi istenmektedir. 
esaslı unsurlarına tesir etmemişimdir? O halde bütün neticelerile suç mevcuttur.

Bazı cezacılar yalnız, herkes ceza kaununlarım bilir addedilir * demekle iktiza ederler ve bu suretle hukukî hata ile fïilî hata arasinda esaslı bir ayrilık muhafaza ettiklerini. iddia ederler. Bunlara verilecek cevabimız şudur:

Kanunun, cezalandırdığı fiiller arasından büyük bir kısmını teşkil eden öyleleri vardır ki temyiz kudretini haiz herkes bu fiillerin cezayı mucip olduğunu, tabiî hukuka aykırı bulunduğunu bilir: Bu fiillerden birini yapan bir kimseyi cezalandırmak için bir saniye (fiction) ihtiyaç yoktur. Kabahatlı kimse iyi bir (Jurisconsulte) farz edildiğinden dolayı değil, fakat ihlâl eylediợi tabiî hukuk kaidesini hakikaten bildiğinden dolayı cezalandırılacaktır. Fakat eğer bu tabii hukuk kaidesini gerçekten bilemiyecek kadar anlayıșsız (borné) ise cezalandırılmayacaktır (Cf. art. 66 Code Pénal). Kanunun cezalandırdı̌̆ı diğer fiiller ise mutlaka hileli bir kasdi icabettirmeyen kabahatleridir, ve fiili hatanında hukukî hata gibi bunları mahzur göstermeyeceği tabiidir. Bundan dolayıdırki herkes her şeyi bilir addolunur, denilmedikçe ortada herkesin ceza kanunu bilir addini icabettirecek bir sebep yoktur. Bununla beraber, bu iki nevi hata arasında yine bir fark mevcut kalacaktır, diye itiraz olunabilir. Bir sanı, hareket tarzının kaçınılması mümkün olmayan fiili bir olayın tabî̂ bir sonuncu olduğu nu isbat ettiği takdirde cezadan kurtulur. Böylece, bir memura arabam içine benim haberim olmadan konmuş okturva resmine tabi bir malın mevcudiyetini beyan etmemen cezayı müstelzim değildir. [1] Bunun aksine olarak sanık, hatta suçun kaçınılmayacak bir hukukî hatanın neticesi olduğunu iddia etse bile yine ceza görecektir. Çünkü Kanunu bilmemek maazeret sayılmaz.» Bu suretle hata kanunen imkânsızdır, ve imkânsız olan bir şeyde zaruri olamaz, (l'erreur de droit est donc legalement impossible, et imposseble nes'àurait être inévitable) Lâkin bu şekildeki ifadeler bize şüphe telkin eder. [2]

Bazı vahim hâdiseler, meselâ bir su baskını, bir düşman is-

[1] Garraud. Op. cit. t. I. p. 560,2 ed.)

[2] Burada zarurî olan hukukî hatalar vardır. Lain'e bakın Traite élèmentaire de droit criminel (1880), No : 205, Haus, Prencipes generans du droit pénal belge ( 3 ed.) No : 659-666. Memur, (agent) iejin bilinmesi mümkün olmayan yeni bir kanun mucibinee sug̣ konusu teşkil edecek bir fiìlî misâl olarak verir. Garraud op. cit. t. p. 550 . 
tilìsı, bazı bölgeleri Fransadan ayırmasiyle yeni neşr ve ilân edilmiş, fakat bu sebebler dolayısiyle bu bölgelerde bilinmeyen bi:- kanun bu mıntaka içinde mecburi mi olacaktır ? $5 / \mathrm{Kasım} / 1870$ ta:ihli kararnamelerinin neşrinden evel herkes bunun aksini kabulde müttefikti. Bu kararnameden beri, eğer resmî gazete bu bölg€ye gönderilmiş ve vasıl olmuşsa, böyle bir şey bahse konu bile olamaz. Gönderilmemiş ise böyle bir sual varid olur. Ve bunu da eskiden olduğu gibi halletmeye mani hiç bir sebep yoktur. [1]

Bizce, hatta daha ileriye gitmek bile lâzımdır. Şöyle daha pratik bir hipotezi göz önüne getirelim: Eğer bir ceza kanunu hakkında mahkemeler az çok belirli bir görüs tarzı takip ederlerken, arısızın bunu değiştirirlerse evvelce hareket tarzını buna göre ayarlamış olan bir kimse bu dełişiklik dolayısiyle ceza görecek midir? Klâsik teori, buna müsbet cevap verir. Fakat acaba bu hal tarzı hakkaniyete uygunmudur? Işte yargıçların kendisine müsâade ve hatta teşvik oldukları şekilde hareket etmiş bir kimse ki bundan dolayı onu yine yargıçların kendileri mahkûm ediyorlar. Yargıçlar; onu, hukuku kendi bildiklerinden daha iyi bilmediği için mahkûm ediyorlar! demek ki kanunların deđ̛̆şmesi makable şămil olmadı̆̆ı halde bir içtihat deł̧rş̧mesi böyle bir tesire malik olacaktır. Bōyle bir mahkûmiyetten; sözde suçlu ve daha umumî olarak halk, vazih olmayan kanunlar karșısında itimat edilir bir rehber bulunmadığı vatandaşlarm hürriyet ve şereflerinin her zaman için tesadüflerin elinde oyuncak olduğu hukukçular karşısında hatta istikbali bilir addolunduklan gibi ne neticeler çıarmazlar kil Acayıp bir sonuç doğrusu! fakat hakikaten, tenkit etmekte oldưogumuz Doktrin ile bundan daha memnuniyet verici başka herhangi bir neticeye varabilinir mi? [2] Bize; kanun bilmemek def'inin ancak kanunun neşrinden itibaren üç gün içinde mahkemelerde dermayan edilebilecę̆gini öngören 1870 tarihli kararnemesinin 4 üncü maddesi ileri sürülerek itiraz edilecektir. Fakat bu geçtikten sonra kanunun uygunlanması lâzımdır,

[1] Planiol'a bakın: de droit eivl, 2 e ed. t. 1. No: 273

[2] Bìe karşı bu teorimizin mahkeme iętihałlarmnn değişmesine mani ołacağı ve bu suretle Jurispsudence si kendisine lâzum olan bir oynaklıktan mahrum edecełi; tenkit yaplinamalıdx. Mahkemeler, bir kanunun yorumlanmasında evvelee yanıldıklarmı anladıkları zaman suẹluyu zaruri olan bu hatasindan dolayı beraat ettirerek kanunları yeni bir yorumlhmaya tabi tutabilirler, ve bu geçiş devresini de dikkat nazarlanna alarak müteakiben kanunu diledikleri gibi tatbik edebilirler. 
denilecek mi? Muhakak surette, bu kararnameyi hazırlayanlar ancak çok doğru olan bir şeyi söylemek istemişler ve normal olan bir vaziyeti; hukukî bir kaidenin muayyen ve bilinebilir bir mevcudiyete malik oldư̆u hususunu; gözönünde tutarak böyle bir kaidenin ilânihaye bilinmedił̧i bahanesiyle uvgulanmasının önüne geçilmesini istememişlerdir. Lâkin elbetteki onlar; hiç bir zaman ceza kanunumuzun 64 üdcü maddesindeki shiç kimse kendisine kat'î surette atfedilmiyecek bir fiilden dolayı cezalandırılamaz s şekilde ifad e edilebilecek olan bu çok genel prensibe darbe indirmeyide düşünmemişlerdir. $[1,2]$

Neticeden: Zarurî olan fiili hatalar gibi, zarưî olan hukukî hatalar da vardır. Hukuk bilginleri (Jurriconsulte) birinin olduğu gibi öbürününde varlığımı kabul ederek her ikisinede aym prensipleri tatbik etmelidir.

B - Eğer halin icablarına göre, hukukî hata bazen bir șahsı mahkûmiyetten kurtarabilirse bizce, evveliyetledir ki tıpkı fiili hata gibi bir cezayı azaltıcı sebep de teşkil edebilir. Sein mahkemesinin alâka uyandırmış yeni bir kararıda bunu teyit etmektedir. [3] Bu kararda şunları okuyoruz: «.... diğer taraftan 9/Aralık/1905 tarihli kanunun yeni olması ve her ne kadar metninin herkes tarafından bilindiğinin kabulü bir kanunî karine icabından isede bu karinenin tatbiki, bazan mahkemenin halletmek zorunda kaldığı cezayı mucip tahrikin mevcudiyeti şartlarında oldư̆u gibi bir çok ince ve tartışma konusu olacak hukukî mesele ortaya çıkarabilir.

Molinier, Traitè théorique et pratique de droił pénal annoté, par vidal, 1893-1894, t. 11 P. 2 09). - Bizce, bir kanunu bilmemek yüzünden hukuka aykır hareket eden bir yabancının vaziyeti; lisamımızl, adetlerimizi bilmemesi dolayssiyle bunlarda fîlî hatalar yapan bir kimseninkine benzetilmelidir. (Bu suretle, gümrükte sandığında ki esyalarınm saymak isteyen yabanemun 1isanda yapacağ bir hata ile yanlıs bir beyanda bulunması gibi.) Hata nadiren zarurî gibì gờrünür, fakat onun hį̣ bir zaman zarurî̀ olmayacă̆ını iddiada fazla ileri gitmek olur.

[1] Sanığm eski bir içtihat tarafindan değilde, haklı olarak itimat etmesi lâzım gelèn yetkili bir makam tarafından hataya düşürülımesi halinde de ayni hol faresinin tatbikini istiyoruz. Bunun aksini kabul eden su yeni karara da bakin: Cass. crimm 1/Mart/1907 Pand. fr, 190, 1. 102.

[2] Fransaya yeni gelmiş bir yabancının pozitif hukukumuzun hükümleri hakkındaki gayrî iradı ve zarurî olan bilgisizliłgini ilerì sürüp süremeyeceği münakaşalarıdlr. Bakıu : (Taurin, 6/Nisan/1898 D. re. N, 3733. - Nimes 13/Haziran/1874 D, 77.5.336. - Metz, 3/Temmuz/1850, 1850, D, 51.2.137. Jouin)

[3] Ceza daire (chambre correctiomelle) 13/Nisan/1908 (procés de I' abbé 
Hukukçular haricinde kalan hatta bilgin vatandaşlar kütlesi bile yasak olanla olmayanın sınırını açık olarak tayinde maruz kalınan hukukî güçlükleri anlayacak bir durumda bulunmaktan uzaktır. Bütün bu türlü sebeplerden dolayı cezanın son haddine kadar ndirilmesi icabetmektedir." Bazı siyasî gazeteler yalnız kararın buraya almış oldư̆gumuz gerekçesini deợil fakat diğer kısımlarınıda şu suretle şiddetle tenkit ettiler: Yargıçlarn kaide haline girmis "kanunu bilmemek özür saylmaz" hukuk meselini tatbik etmemeleri tuhaf değilmidir? [1] Bu kaideye nazara almamak hoşunuza gitmeyen bütün kanunların uygulanmasını ortadan kaldırmak için ne güzel bir çare! Bizi anarşiye karşı müdafaa etmeleri lazım gelenler tarafından ona doğru atılmış bir adım! Zaten 5/Kasım/1870 tarihli kanunda (Mad. 4) Kanunu bilmemek def'inin mahkemelerce kabulünü ancak kanunlarm neşrinden itibaren üç güne hasretmiş olduğuna işaret etmeyede lüzum var mıdır? Evet elbetteki yargıçlar bu üç günlük müddetin geçmesinden sonra suçluyu; sırf kanunu bilmemesinden dolayı berat ettiremezler, lâkin bu sebebi; pekâlâ bir azaltıcı sebeb olarak suçlu lehine nazarı itibare alabilirler, diye cevap veriyoruz.

Maliye bakanının bir notu bunu zımmi olarak kabul etmişe benziyor. [2]

Hakikaten, kanuna karşıı bir def'î dermeyan etmek bir bakımdan onu tatbikten uzaklaştırmak demektir, halbuki azaltıcı sebeblerin varlığın iddia eden taraf ceza kanununun 463 üncü maddesindeki genel prensiple birlikte göz önünde tutulmasını istemek-

- tedir. Ne hakla, «cezayı azaltıcı sebeblerin mevcudiyeri halinde, cezayı indirmek lâzımdır.) Diyen ve tamamile genel olan bu prensibin tatbiki bir tarafa birakılabilir. Cezayı azaltıcı sebep, olarak herhangi bir vak'anın hatta kanun koyucunun kanunî bir maazeret olarak kabulünü red eylediği vak'aların bile ileri sürülecȩ̌̆i muhakk:ak iken neden hukukta (hukukî) hata iddiası, burada kabul olunmagın! Insanın karşı koymasını bilmesi lâzım gelen; serhoşluk, siyasî ihtiras, aşk, kıskançlık gibi bir çok sebebler cezayı

[1] Bu konu hakkanda meselâ (petit république gazetesindcki yazılara Bakın 14/Nisan/1907

[2] Maliye bakanmm 12/Nisan/1907 tarihinde yaymlamms olduğa bu notundá Maliye bakanlığl; damga kanunun ihlâlinden doğan sựlarda, bu kanunun tatbikinin otazbes seneden fazla bir bir zamandanberi devam edegelmısi dolavısiyle hükümlerini bilmemenin bir özür sayılamıyucağı eihetle œ̧ok sert davranılması hakkında; ciddi emirler verecektir., denilmektedir. 
azaltmaya müsait iken; neden ruhu, daha iyi kavramamış bir kanunda yapilan hata, hatta önüne geçilmesi mümkün olmayacak bir hata cezayı azaltmaya müsait olmasın. Kanun koyucu yargıçIara "ceza tayin ederken hâdisenin bütün sebeblerini hukukî hata hali müstesna göz önünde tutacaksınız, ben bu hata üzerine içine girilmesi mümkün olmayan öyle bir örtü örtüyorum ki kaldırılması aslâ caiz.değildir mi?» Demiştir! Bilâkis kanun koyucunun 1832 de ceza kanununun 463 üncü maddesini değ̌ştirerek bu günkü şeklini verirken ki maksad,, niyeti hatırlansın bilhassa cezayı azaltmak sistemine; yargıçlara önlerine gelen suçun nevine göre; ceza sistemimizi tekrar gözden geçirme imkânı veren bir vasıta gibi bakıyordu. Meselà Ölüm cezasını kaldırup kaldırmamak; teşebbüsü tam fille; asıl faili hem fiille benzetip benzetmemek gibi.» [2] $\mathrm{Bu}$ suretle bu meselede bütün kanunlar; kanun koyucunun isteơgile yargıcın vicdanı önünde eğilecek, fakat yalnız bir prensip, «kanunu bilmemek özür sayllmaz", prensibi dimdik hepsinin, hatta yargıcın vicdanı üstünde. halkın önünde saygiyle eğildiŏi bir mabut hatta bir hükümdar gibi duracaktır. Fakat acaba nasıl oluyorda bu hiç bir kanuna istinat etmeyen bu; yalnız bir fictiondan ibaret olan, bu; adaleti ihlale gōtüren prensip öyle büyük bir hürmete lâyık oluyor?

Bize göre, hukukî hatayı bir azaltıcı sebeb olarak kabưl eden bir yargıcı, bundan dolayı muaheze etmek kendimizinde hukukî bir hata işlemesi demek olur. Bu suretle bu kaideden (hukuk meselinden) çıkan ikinci neticenin incelenmesi, bizi elbetteki ceza kanunu her zaman uygulanmalıdır, hukukî hata fiili hata gibi kanunun ihlâline bir sebeb teşkil etmemelidir. Lâkin ne fiili ve nede hukukî hata yok (Gayri mevcut) addolunamayacağından, bỉrinin hukuki sonuçlar tevlit ettił̆i yerde öbürüde bôyle sonuçlar doğurmalıdır, mülâhazasına götürür.

C - Ceza hukukunda yapmış olduğumuz bu mukayeseye medeni hukuk alanında da devam edecey̌iz. Bize kbir kanundaki hak düşümü, zaman aşımı hükümlerine uygun hareket etmemiş olan kimse kendisine bunların uygulanmasının önüne geçmek için cehaletini ileri süremez., Diyorlar. Itiraz kabul etmeyen ve hiç bir fictionu icabettirmeyen bir kaziye. Fakat çok daha sade olan hakikat şudur ki: Kanunlar hakkındaki bilgisizlik maddî vak'alarda da oldư̆u gibi kanunların nizamlamış oldukları vak'alara

[2] Garravd. 7. eit. t. 11, P, 561. cheuvvau, c. peu. pogressif, P. 16 
tatbiklerine mani teşkil edemez. Çift bir misâl bu muvaziliğin doğrult:ğunu gösterecektir: Daktorların; muayene ücretinden doğan alacaklarının üç senelik bir zaman aşımına tabi olduğunu zanneden bir doktora, bu dava hakkının muayene tarihinden itibaren iki senzlik bir zaman aşımına tabi olduğu hakh olarak ileri sürüleeektir. Isste diğer bir doktor ki bu alacak davasını iki senelik bir zarman aşımına tabi olduğunu bildił̆i halde tedavi ettiği iki hastayı karıştrak 1905 de baktığı hastayı 1906 da tedavi ettiợini zannetmiştir. Bu fiili hatasına ră̆men ona da bu iki senelik zaman aşırı def'i iler sürülecektir. Hal böyle iken doktorların hastaların kesin olarak hangi tarihte tedavi ettiklerini her zaman için bilir addolunduklarına dair bir fiction icat etmeği, kimse hatırına bile getirmemiştir.

D - Bu kaideden çkan neticeleri incelemekte devam edelim: Kanunî bir vecibeyi yerine getirmemek suretiyle bașkasına bir zarar veren kimse; hiç bir zaman kanunu bilmediğini ileri sürerek hukukî; sorumluluktan kurtulamaz. Şimdiye kadar gösterdiğimiz sebepler dolayısile, hukukî hatayı tiili hataya teşbih eden biz; böyle bir vaziyette evvelâ fiili bir hatadan bahsedildiği zaman nasıl bir hal tarzına varılacăğın arayalım:

Fiilî bir hata neticesi hukukî bir kaideyi ihlâl eden bir şahıs, genel olarak, bu suretle yapmıs olduğu zararı tazmine mecbur tutulur. [1] Meselâ bir avcının uzaktan hayvan zanniyle bir insanı yaralaması halinde; prensip; bundan sorumlu olmasidır. Bir mülk sahibi; üçüncü bir şahsın doğru olmayan bir raporuna istinat ile arazisi üzerinde komşularının zararına yaban tavşanlarının lüzumundan fazla çoğalmasına müsaade etmesinden dolayıda prensip olarak mes'uldür. Fakat ę̆er zarar yapan şahıs; kaçımılması kat'iyyen mümkün olmayan bir hatanın kurban olduğunu isbat ederse bu takdirde bütün sorumluluktan kuatulur: Meselâ bir fuarda karabine ile eksersiz yapmya tahsis edilmiş bir barakada, tüfek talimi yapan bir kimsenin silâhından çıkan kurşun barakanın duvarının iyi yapılmamış olmasından dolayı bir maniaya tesadüf etmeyerek dışarı çıkarak oradan geçmekte olan birini yaralasa; bundan

[1] Klâsik drænsipler, bir şahsın fiili hatasınm bir kusnr teşkil èmesi halimle; bu şalıs mes'ul adddederler. Halbuki böyle vaziyetlerde, mahke-

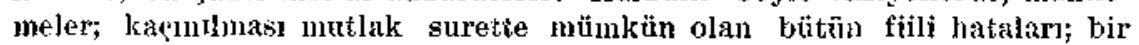
kusur gibi telakki ederler. Bu suretle bizim iddiammzmo hakl ofduğ meydana ikar. 
dolayı silâh atmış olan şahıs tazminatla mahkûm edilmiceyektir. [1] Bizce; fiilî hata yerine bir hukukî hatanın mevcudiyeti halinde de mesele ayni şekilde halledilmelidir. Bize göre haksız fiilin faili mes'uldür. Lâkin bu hususta M.M. Aubry ve Rau gibi yazarlardan [2] ayrılmaktan duyduğumuz bütün tessüre rağmen, biz sorumluğun, haksız fiil failinin; hakikaten zarurî olan bir hatanın kurbanı olması halinde ortadan kalkacağını kabul ediyoruz. [3] Meselâ bir şahıs muayyen bir zamanda mahkeme içtihatlarının diledigi şekilde hareket etmekte iken, birdenbire mahkemeler ansızın içtihatlarını deð̆iştirse, böyle bir vaziyette; bu adamı evvelce ika edebilecek olduğu bir zarardan dolayı tazminat ile mahkûm etmek; bize insafsız bir hareket gibi görünüyor. [4] Hiç olmasa biz, mahkeme kararlarında ortaya attı̆̆ımız nazariyenin enteresan bir tatbik tarzını buluyoruz. Bilindiği üzere Noterler; Prensip; olarak yaptıkları veya müşterilerine yaptırmış oldukları (Müşterilerinin yapmasın müsaade ettikleri) hukukî hatalardan sorumludurlar, fakat yargitayın bir kararı bu kaidenin sertliğini biraz tahfif etmiştir. «Noterler ciddi surette tartışmalara ve şüphelere mahal vermekten çıkmıs bir hukukî mesele hakkındaki hatalarından dolayı sorumlu telâkkî olunurlar. [5]

Sein mahkemesi de aymı şekilde "tartışma konusu olan bir mesele üzerinde Noter tarafından yapılmış olan hukukî hata kat'iyyen sorumluluğu mucip olamaz, diye karar vermiştir. [6] Bu kaideye yapılmış olan bu tahfif hakkaniyete en uygun olanıdır.

[1] Baraka sahibi ięin vaziyę büsbütün başkadır.

[2] 5 e. ed. t. 1. P, 94

[3] Bütün bu meselelerde; biz hukukî sorumluğun evvelden mevout bir kusuru veya maddî (fiili) bir vak'ayı icabettirip ettiremiyeceği hakkındaki görüsllerden birine ilsihak etmekten çekiniyoruz. Bu mesele M. Saleille tarafundan (théorie general de l'obligation 2. de. P. 376, Noté 1) ortaya atılmıs ve o zamanından beride bir ৎ̧ok yazarlar tarafindan tekrar ele alnmıştır. Kabul edilecek sisteme göra muhtelif hal tarzlarını meydana ękacağı tabiidir. Fakat her hal tarzında fiili ve hukukî hataya aynu prensip tatbik olunabilir. Buda bizim nazariyemizin meveut her iki sisteme uyması iç̣in kâfidir.

[4] Böyle bir halde tazminat kendisinden dava edilen bir şahıs maruz kahnan nararın hakikî müsebbibi degildir. Bu zarar terk edilmiş olan iẹtihadın tabî̀ bir neticesidir. Ve bu bakından da hareket tarzı kusurlu olmak şöyle dursun hatta normal olan kimseleri mahkûm etmek âdî olmaz.

[5] Ass. 24/Mayıs/1886, pand. franழ. 86.1.157 (Notada bakmiz.)

[6] Trib. Seine, 1. ea. ch. 12/Mart/1889 pand. Franç. 90. 2. 104. 
Lâkin bu yalnız noterlere hasnı edilmemelidir, çünki kanunda hata, yapmak sadece kanun adamlarına münhasır değildir. Bu suretle ister bir hukukî kaidede, ister basit bir vak'ada cahillik (hata) edilmiş olunsun, bize göre tek bir adalet olduğu gibi tek bir bilgisizlik (hata) vardır, ve gerçekten hiç bir kimse kendisine atfedilmeyecek fiillerden, dolayı hukuken sorumlu olamaz.

E - Bu kaideden (hukuk meselesinden) çıkarıldığg iddia edilen diğer bir netice daha: Hususî hukuk; bir kusurun hüküm ve neticelerini onun ağırlık derecesine göre tayin ettiği hallerde bizeł; hukukî hata, kusurun derecesini tayininde hiç bir şeyi değiştirmez diyorlar. [1]

Biz ise, bunun aksine olarak hukukî hatanında fililin̂ hata gibi aynı şartlar dahilinde bu hüküm ve nâticeyi değitireceğini kabul ediyoruz. Bir misal verelim: Çok defa mahkemeler; bir iş veren tarafından, amelelerin yapacaklan kazalara karşı yaptırilmış olan sigortanın; fahiş bir kusur ve kanun ve nizamlara kasden karşı gelme halleri müstesna; işvereni hattâ kanun ve nizamların tatbik edilmemesinden doğan zararlara karşıda himaye edeceğini ve ssorumlulư̆u mucip maddî (fiilî) vakaların ağırlıkların tayin ve takdirinin bu davaya bakan mahkemeye ait olacağına» karar vermişlerdir [2].

Bir iş verenin, yeni ve açık olmayan bir hukuk kaidesini yanlış yorumlaması yüzünden bir kaza olduğunu farzedelim, bu keza; eğer bu hüküm iyi anlaşılmış ve uygulanmış olsaydı mey-

[1] Birinci partinin $\mathbf{F}$ harfinde gösterilen bolli baģlı vaziyetlere bakın.

[2] Paris: (1. er. Chambre, 10/Kasm/1893 pand, )r. 94. 2. 225) - ayn

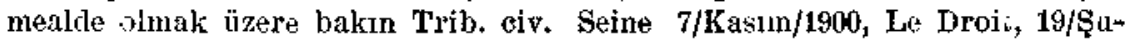
bai/1901 gaz des. trib. 1/Haziran/1901. - Eger sigoria şirketleri, sigoria polię̧eleri içine şahıslamn emniyeti iẹin (Sureté des pernomnes) kommus olan kanun enir ve nizamlara muhalif bütün hareketlerin sigoriadan faydalanmał̆a mani olacağına dair bir şart (elause) koymak adejinde olmasalard, bu içtihat tarışma götürmez bir surette bütün tenkjdlerden uzak kalırdı. Bu şarłn meveudiyeti böyle bir içiłhadı münakaşa göıütür bir hale sokmaktadır. Bumunla beraber, hattâ bazı sigoriaeların bile $\dot{I}_{\zeta ̧}$ hukuku hakkkındaki hükümlerin, son derece karışık ve iş verenlerinde bıt sebeple, bunları lâyıkiyle tatbikde içinde bulumdukları imkânsızlık dolayısiyle poliçedeki lu şarìn harfiyen uygulanmasm sözleşmeyi aşağı yukarı bir hükümsüz haiı sokaçăgn kabul ettiklerinl duyduk. Bu sebepledirki ekseriya ciddî orialıklar, (şirketler) bu şarttan faydalanmaktan kaçınmaktadırlar. Her ne olursa olsun böyle bir içthihadm meveudiyeti onu nazar itibare almamz jẹin kâfidir. 
dana gelmiyecekti. Ĕğer işverenin iyi niyeti açık ve metnin müphemiyeti yüzünden hatası mahzur görülebilirse; bunlar göz önünde tutularak fahiş bir kusur karşısında değiliz, tazminat sigortacınin zimmetinde kalmalıdır, denilmelidir. Evet şüphesiz ki adalet bu şekilde hüküm verilmesini icabettirir. Eğer bir işveren, bilmiyerek ihtiyari haricinde olarak bir kanunu fiili bir hatasıle (meselâ haberi olmadan bir makinenin; bu makineyi muhafaza eden kısmından (appareıl protecteur) ayrilmış olması gibi) ihlâl etmesi halinde sigortacının bunu tazmin etmesi lâzım geldiği kabul olunur, Hatar:ın karanlık, vazıh olmayan bir metnin anlaşlamamasından ileri gelmesi halinde, aksi şekilde karar verebilmek için hangi metine ve hangi mantığa dayanilacaktır?

$F$... Incelememize devam ederken bu kaidenin son derece önemli bir neticesine vasıl oluruz: Bize, bir başkası tarafından bir hukukî kaidede aldatılmış (hataya sevkedilmişs) olan şahıs, kat'iyyen öbüründen sebebiyet verdiŏi zararın tazminini isteyemez. çünkü kanunu bilmesi lâzım gelirdi. deniyor. Bizce, bu kaideyi burada da zikretmek, adalete uygun olmadıł̆ının açıkça meydana çıması için kâfidir. Fakait yargıtayın kararlarını bizim karşım.za çıkarıyorlar: $O$, tren memurlan, tarafından resmen tasdik edilmiş tarifeler üzerinde hataya sevkedilmiş olan bir yolcunun; bir mal gönderenin (expediteur); zararının tazminini ‘kanunu bilmemek özür sayılmaz» diyerek kabul etmez. Hiç şüphesizki yüksek mahkemenin otoritesi bize saygı telkin eder; Ancak biz yüksek mahkemeye karşı yine bizzat kendi otoritesiyle karşı koymak cesaretinide kendimizde görüyoruz. Hakikaten; eğer prensip olarak; doğru bilgi verilmemiş olan bir kimsenin ka unlan bilmesi lâzım geldił̆i bahanesiyle hiç cir ceza görmeden bır şahsı; hukukî bir hata yapmağa sevk edilebilir veya hukukî hata yapmasina göz yumabilirse, yargıtay neden mes'uliyet tehdidi altında noterleri rmüşterilerini bilhassa bilgisiz (cahil) oldukları zaman giriştikleri taahhütlerin hüküm ve neticeleri hakkında aydınlatmak ve onların hukuk kaideleri hakkındaki noksanlarını tamamlamak «zorunda olduklarını kabul etmiştir? [1]

Şuna iyice dikkat etmek lâzımdırki bu prensip (yargitayda bu cihete işaret etmiştir) noterler hakkındaki hiç bir özel kanundan çıkmaz. Temyiz dilekçesinde de söylendiợi gibi bir medeni ka-

[1] Cass. 9/Kasim/1904 gaz des trib. 28/0cak/1905. Bu prensip mahkeme karariannda daima meveuttur. 
nunur: 1382 ve 1383 üncü maddelerindeki genel kaidelere idir. Eiğer hakikaten herkes kanunu bilmekle mükellef olsayd, dava edilen noter" benden tazmini istenen sözleşmeleri, muameleleri usulü dairesinde yapmakla benim ișim biter, geri kalan cihet bıni ilgilendirmez, herkes kanunu bilmekle mükellef olmasina göre inüşterilerimin hataları yalnız onlara atfedilmelidir d diyebilmeliydi, ve zaten onun için de noterin; hiç bir bakımdan da mahküm edilmemesi lâzım gelirdi. Cünkü yanlış bir bilgi vermemiş, yalnız bir şey söylememekle iktifa etmişti. Halbuki yukarda da işaret etmiş olduğumuz üzere, tren kumpanyaları müşterilerini bizzat kendileri yapmış oldukları hukukî muamelenin neticeleri üzerinde hataya sevk etmişlerdi.

Yukardakilere benzemiyen diğer bir vak'ayı da zikredelim: Bir kanunu, Maçon komününe alınma tarzı iz işleri bakanlı̆̆ı tarafından onanmak şartiyle istikrazda bulunmak selâhiyeti vermişti. Bunun üzerine belediye reisi bir bankacı ile bu hususta bir anlaşma imzaladı, bu anlaşma iç işleri bakanlığ̣ tarafından tasdik edilmedikçe hüküm ifade edemiyeceð̆ine rağmen, bankacı Fransanın her tarafında yaptığı ilânlar ve astırdığı afişlerle kendini Maçon şehri hesabına istikraz yapmał̆a memur edilmiş gibi gösterdi, ve hükûmetin daha bu hususta hiç bir selâhivet vermemiş olmasına rağmen tahvilât satışına başladı. Maçon şehrine istikrazda bulunduklarını zannederler karşılarında borçlu olarak yalnız bankacıyı bulunca, Maçon şehrini; belediye reisinin hiç ses çıkarmıyarak kendilerini hataya düşmekten men etmemiş olmasından dolayı dâva ettiler.

Bilindiği üzere komünlerin sorumluluğu medenî hukuk hükümlerine tabidir (C. c. art. 1382 vd.) Maçon şehri tren kumpanyalarını resmen tasdik edilmiş tarifelerden doğan hatalarda ileri sürdükleri müdafaayı kendi lehine dermeyen edebilir ve istikrazın bir kanunla yapilmasına müsaade edildiginden bahisle bu kanunda istikraz için konan şartların bilinmesinin bir mazeret teşkil etmiyeceł̆gini bu zarardan yalnız istikraza hükûmetçe müsaade verilip verilmediğini tahkik etmeden iştirak eden ferlerin mes'ul olacağını; ve hatta tren kumpanyalarının yukarda işaret edilen vaziyetlerde iddia edebileceklerinden fazla olarak belediye reisi, istikraza iştirak edenlerin hataya düşmelerine mani olmamişsa bile bu hataya hiç bir suretle sebebiyetde vermediğgini kendi lehine olarak dermeyen edebilirdi. Buna răgmen yargitay, 
Maçon komününü belediye reisinin sükûtundan doğar zarardan sorumlu addetti [1].

Bütün bu kararlardan; hiç bir mes'uliyete uğramadan başkalarını kanunlar hakkında hataya düşürülemiyeceğ́i neticesi çıkar. Zaten yüksek mahkeme bir komisvoncunun; müşterisine kokocasın!n rızasını almadan evli bir kadın tarafında imzalanmıs bir borç senedinin ne kadar az bir kıymeti haiz olacağın bildirmeden vermesinden dolayı sorumlu olması lâzım geldiğinden bahsile Montpellier mahkemesinin (yukarda işaret edilen) kararımı boşuna bozmamıştır.

Lâkin bize; tren memurlarının tarifeler hakkında müşterilerine yanlış malûmat vermelerinden dolayı doğan ihtilâflar hakkundaki mahkeme içtihadlarmı nasıl izah edeceğimiz sorulabilir! Belki bunu izaha lüzum da yoktur. Çünkü hakikatte, mahkemeler karalarında tam bir birliğe varmaktan çok uzaktırlar. Mahkeme kararları; türlü işlerle türlü zamanlarda uğraşmış bir çok kimselerin yapmış oldukları intellektüel çalışmaların neticesinde meydana gelen bir şey olduğundan bizim iddiamız teyid eden bir çok kararlar yanında ona muhalif olan bazılarının bulunmasında hayret edilecek bir şey varmıdır? Zaten bizim görüşümüze muhalif olan kararları; sk sı tesadüf edilen ve hatırlanması lüzumlu olan bir olay izah eder :

Bir tren kumpanyası, bir yolcudan veya bir mal gönderenden resmen tasdik edilmiş tarifelere dayanarak munzam bir ücret istemişti. Ticaret mahkemesi kumpanyaya prensip itibariyle hak vermekle beraber «kumpanya tarafindan talep edilen bu paranın mal gönderene zararı ziyan olarak hüküm edilmesi lâzımgelen ayni miktardaki para ile takas edileceğini * ilâve etmiști. [2]

Bu suretle her şeyi sanki yanlış olarak alınan ücretin hiçbir talebe meydan vermiyeceø̆i gibi cereyan ediyordu. Yüksek mahkemenin de hoşuna gitmiyen işte bu idi. $O$; tasdik edilmiş tarifelerin mecburî oluşuna (force obligatoire) bunun bir darbe indireceł̆inden korkarak ticaret mahkemesinin kararlarını bozmıya başladı. [3] Bu içtihadın, tasvip edilmemesi icap ettiğini kabul etsek

[1] Cass, 16/Nisan/1894 pan. Franç. 95. 1. 89

[2] Verdiłgi karar 13 şubat 1878 S. 78. 1325 tarihli ilàmla bozulan Mont* batan Ticaret mahkemesi de böyle yapmıgtır.

[3] Bu sebep, surf hukuk bakımından yüksek mahkemenín iq̨tihadım dơgra göstermek iẹin kâfi midir? Biz tren tarifelerinin hukukî mahiyeti hakkmdaki etüdümüzle bunun aksini ispata calıştık. (P. 131. vd.) 
bile onun istisnai olan mahiyetini göz önünde tutarak sair hallerde bu prensip yerine âdil olan şu prensibin sbir başkasının hukukta hât.x etmesine müsaade eden veya ona hukukî bir hâta işleten şahıs fili hatalarda sorumlu olduŏgu şart ve derecelerde mes'ul olmalıdir.» tatbik edileceğini ümit ediyoruz.

G - Bu kaideden çlkarılmak istenen son bir sonucuda inceiiyelim: Medenî kanunun, hataen ve iyi niyetle hareket etmiş olanları himayeye dair olan özel hükümlerinden; bu hatayt hukukî bir kaidede yapmış olanların istifade edemiyecekleri söylenerek [1] bunun hakkında biri mantığa (kanunu bilmiyenlerin, kanunu bilenlerin zararına olarak himayesi dơ̆ru olmaz), diğeri de mahkeme içtihatlarına dayanan (bize içlerinden bir çơ̆u yargıtaydan çıkmış kararlardan bahsederler.) iki delil gösteriliyor.

Biz ise bunun aksine olarak bahse honu ipotezde de hukukî hatann fiili hataya benzetilebileceğini zannediyoruz:

Evvelâ, mantığa dayanılarak bize karşı koyulan delilin her iki nevi hataya da ayni şekilde tatbik edilebilir olmak hassası vardır. Bize «ne için kanun koyucu, hukukta hâta edeni etmiyene kar:s1 himaye edecektir " diyorlar. Bizde «ne için kanun koyucu mevzuubahis maddelerde, hiç olmazsa maddî (fili) bir meselede hâta edeni böyle bir hâta yapmamış olana karşı himaye etmiştirs diye cevap veriyoruz. Bize hukukî hatayı mahzur göstermek, itaatsizliği ve ihmali teşvik etmek değil midir? deniyor. Biz de cevap veriyoruz: Fiili hatayı mahzur görmekte ihmali ve ihtiyatsızlıł̆ teşvik dẹ̛̆il midir? Hakikatte, hâta etmiş olanları himaye maksadiyle konulmuş olan kanun hükümlerinin her iki nevi ha“ tada da ayni kıymeti haiz olan bir sebebi vardir. Böyle vaziyetlerde kanun koyucu, üçüncü şahıslara; ehemmiyetsiz veya tama* men arizî veya kolaylkkla def'i kabil veya muayyen bir nisbette müstahak bulunduklan bir zarar tahmil ederek iyi niyetli kimseleri hatın sayılır bir zarardan kurtarmayı daha yerinde bulmuştur. Ne için eski bir samın, (fiction) tesiri altında bir yarı adaletle iktifa ederek bu kadar dơgru (adil) olan kaidelerin tatbikini keyfi olarak sinırlamalı (tahdit etmeli)? Bir misal verelim: Umumiyetle medenî kanunun 201 inci maddesindeki «batıl addedilmiş bir evlenme hüsnüniyetle, aktedilmiş ise kanı koca hakkında oldư̆u gibi çocuklar hakkındada hukukî neticeler tevlit eder»

[1] Bunun belli baş̧ı misallerỉ medenî kanunun 201, 549, 1109, 1110, 1299, 2265, 2279 uncu maddelerindedir. 
kaidesi herkes tarafından tasvip edilir. Bunun bir hukukî hâta dolayisiyle mevzuubahis edildigini farzedelim: Evlenmeyi Fransada yapacak olan belediye reisi son dakikada bir mazareti yüzünden işi başına gelemiy.or, yerine selâhiyettar olmıyan bir başka memur geçiyor. Selâhiyet hakkındaki kaideleri bilmiyen nişanlılar da boş yere sahi bir şekilde evlenmiş olduklarını zannediyorlar. Bu taktirde bunlara 201 inci maddeden istifade hakkı reddolunarak saơlam bir şekilde kurulmuş zannedilen yuvayı yıkmak, doğması muhtemel çocuklara tabii çocuk nazariyle bakmak, sanki babalan anaların yalan vaitlerle aldatarak iğfal etmiş ve sanki anaları da baştan çıkarılmış bir $\mathrm{kIz}_{\mathrm{I}}$ imiş gibi ana ve babalarına bir nevi mânevi leke vurmak çok sert olduğu gibi kanun koyucunun maksadına da muhalif değil midir? [1]

lyi niyet her zaman için iyi niyettir, bunu ortadan kaldıracak bir fiksion olmadıø̆ı, gibi kanunun bazı inceliklerini bilmediklerinden dolayı bir ailenin yıkılmasına da bir fiksion yüzünden müsaade edilemez ve sözde bazı içtimaî zaruretlerde hiçbir zaman böyle anti sosyal bir neticeyi haklı gösteremez. Buna benzer bir mülâhazayı, dił̆er mevzuubahis metinler hakkında da ile süreceğiz. Zaten bunları bize karşı ileri sürülen ikinci delile (argument), mahkeme içtihatlanna, cevap verirken daha yakından incelemek fırsatını elde edeceğiz.

Bu görüs tarziyle; belki de en mühim meselelerden biri olan hukukî muamelelerdeki hatayı tetkik edenler, bize bilhassa kasten (à dessein) taraflardan birinin hukukî hatasını nazari itibare almamış bazı mahkeme kararların gösterirler. Bu kararlarında dơ̆ru oldư̆unu çünkü bir hukukî muamelenin hüküm vè neticeleri hakkında yanlış malumat edinmiş olan bir kimsenin bu bilgisizliğinin fena neticelerini ilgililere, (meselâ kendisiyle sözleşme yapmış olanlara) yükletilmesinin haksız olacă̆ını söylerler. Lâkin evvelâ doktrin ve sonra da mahkeme kararlarının ekserisi bizimle beraber olarakbu konuda, bu iki nevi hatanın yekdiğerine benzetilmesi reyindedirler. [2] Bazl yargitay ve mahkeme

[1] Bizim fikrimizin lehinde olmak üzere bakm : Trb. eiv. Bruxelles, 15/aralık/1887 Pand. fr. 87.5.7. Trib. Civ. Orléan, 12/Temmuz/1893 ibid. 94.5.36

[2] Bakın: Mérlin rép vo Testament, sect. 2, 5, - Marcadé, 1376 ve 1877 inci maddeler hakkinda. - Morlon Revue pratique, 1864 t. XVIII P. 198. - Laurent, t. XVI 15, P. 505,508. - Hue. VII, P. 21 Baudry Lacan inerie et Barde t. P. 70. - Aubry ve Rau 5 e. ed. t. IV, P. 496. - Planiol, 2 e. ed. t. 
kararlarının, bir hukukî muameleyi taraflardan birinin bir hukukî hatası yüzünden iptal etmeyi reddettikleri doğrudur, fakat ayni şekilde bazları bir fiili hâta sebebiyle de böyle bir muamelenin iptalini reddetmişlerdi. Bu husus bazı izahatı icap ettirir:

Medenî kanunun 1109-1110 uncu maddelerinin hukukî hata halinde kayıtsız ve şartsız uygulanmasımın çok kereler bizi; bir adı̊letsizliğe götüreceğini zahmetsizce kabul ediyoruz, fakat fiilî hata halinde de bunların kayıtsız ve şartsız tatbiki tamamiyle ayri sonucu doğurur. Onun için, mahkemeler; tatbikatta bu iki małdeyi büyük bir tashihe (correction) tâbi tutarlar. 1109-1110 uncu maddeler mantıken ayrilması mümkün olmıan iki meseleyi birbirinden tefrik ederler: Hatadan kim sorumludur? «ve sözleşme iptal edilecekmidir?" Jurusprudence; bu iki mesele arasında aklı selimin icap ettirdiği bir bağlılık tesis ederek, bir hukukî muamelenin, hata dolayısiyle (fiilî veya hukukî) iptalini; iptal istiyen tarafın kusuriyle bir hata işlemiş olması ve bu iptalin de diğer tarafa müsbet bir zarar vermesi mümkün hallerde, kabul etmemiştir. Bu suretle okumak bilmiyen bir şahsın, ilânlarda yazıl bir oyunun mahiyetinde aldanarak bir bilet aldıktan sonra bu hatasını en tatmin edici bir şekilde isbat etmesi halinde bile medenî kanuna rağmen sözleşmeyi jptal talebi reddedilecktir. Çünkü aklıselim bunu böyle istemektedir. Tatbiki hukuk ilminin (Pratique jurisprudentielle) bizim söylediğimiz istikamette olduğunu isbat bizce kolaydır. Bir sözleşme mevzuunun esas vasfına hata eden şahıs, çok defa bu hatasından sorumiudur ve böyle bir vaziyette 1109-1110 uncu maddelerin tatbiki mahkemeleri bu mukavelenin iptaline ve bundan zarar gören şahısların zarar ve ziyanlarının tazminine karar vermeğe sevketmelidir. [1] Halbuki

1. P. 280. - A. - dde Besançon 1/Mart/1827, D. Rép, Óbligations No: 147. 一 Grenoble, 24/Temmuz/1830 S. 31. 2. 35. - Limeges, 8/aralı/1837, S. 39. 2. 27. Cass. Civ, 12/Mart/1845. S. 45. 1.525 Agen 17/May1s/1887 ve temyiz üzerine Ré đ́ 38/mayı/1888 S. 89.1.248. - Chambéry 1/Ocak/1894. D. 95.2.235

[1] Bir sałış akdi üzerine muhakeme yürüten colmet, Santerrove D:mante'a bakn: Onlar eekseriya müşteriyi; satıe ile anlaşmasıı lâzaıı geldigrinden bahisle haksız çkarmak büyük bir itiyatsızlık olur. Müşterinin bu kusuru 1382 inci madde mucibince bir borȩ doğumalid̄or ve bunun netie si olarak eğer satıe mukavelenin feshinden bir zarar görmüşse, bilhassa bix başka satış iınkânı kậrmış ise, müş̧terinin sấııya tazminat vermeși lâzum gel ir» diyorlar. 
mahkeme kararlar külliyatina bakarsak bu hal tarzının tatbikatça bilinmediơ̆ini görürüz. [1]

O halde tatbikat hangi hal tarzını kabul ediyor? Bazı defalar, hata etmiş kimsenin kusuru çok hafif görülerek kendisine hiçbir sorumluluk yükletilmek istenmiyor. Yargıçlar dâva olunan taraf lehine hiçbir tazminata hüküm etmeden sadece mukaveleyi feshediyorlar.

[1] Kararlar külliyatındaki araşiırmałarımz kàfi görülmiyecek midir, kendimizi tatmin ięin iẹlerinde Jurisprudence larm bol bol, bulunduğa saix eserlere meselâ Dallos Réperioire na (v. Obligation 43,45 ) ve onun supplement ina (cod, v, P \& 42 vd.) veyahut ta Aubry ve Rau unu büyük eserinin son edisionuna (i. v, P. 497) baş vuralım : Bu son eser bizi yalnuz 1872-73 de karara bağlanıış tek bir meseleye yollar, Dallos Repértoire I fazla olaraktan bize 1864 tarihli bir karar gösterir. Tatbikatına çok tesadüf edilmesi icabədən bir prensibi izah iẹin iki karar. Bilhassa bunların yanında tartışma konasu teşkil etmiyan az önemli prensipler için birçok kararlamn meveudiyeti karşsında hakikaten psk az fakat dahası var. Bize gösterilen kararlare dönelim: Bəsançon mahkemesinin 8/Kasım/1872 tarihli kararı (Sous Cass Req. 30/Temmuz/1873 D. 1.330.) mukaveleyi iptal ediyor, fakat zarar ve ziyanna hükmetmiyor. Meseleyi tetkik eden yargntay ise istinaf mahkemesinin kararını onaylamakia baraber gerekçesinde zumn olarak * bir zarar meveat olsaydı, bunun için tazminata hükmedilmesi lâzum gelirdi* reyinde bulunuyorsa da iptal talep eden davacıyı hiebir tazminatla mahkûm etmemiştí. Bu suretle, bu prensip yargtayea platonik bir tarzda kabul edilmişse de fiiliyatta bunun tatbikini kac'iyyeü görmüyoruz. Dallos supplement Inın aiıf yapiığ diğer kararda ise (caa. 19/0cak/1864, D. 64. 1. 62) tazminattan bahis bile vok, bu bize onun burada bulunmasımn bir hâta neticesi olduğu hissini veriyor. «Pandectes françaises" de bu jurisprudence eksikliği (klâsik kaidəye dayanılarak) şöyle izaha çalışıyor: ‘Bundan başka şuna da işaret etmek lâzımdır ki (bu observation mukavelesinin feshinde görülmesi mümkün serłliği biraz gidermek į̣indir) mïşteri fesih hakkındaki davasın güçlükle kazanabilir (çünkü muvaffakiyeli, hatanın isbatı jęin gösterec əği delillere tabidir ki bu vaziyette de delil tedariki kendisi için oldukęa güę̧tür. (Pand. Franç. v: Obligations, No: 7159).

Hipotezimizdski, hatanm isbatının billhassa müşkül olduğu hususu bize aęıkça yanlış görünüyor. Hatayı isbat bakınından bir kimsenin kendi kusuru ile veya kusuru olmaksızın aldanmıs olması önemli değildir. Artık çalışamıacak olan ẹift atı yerine bir başkasının almak istiyen ciftẹi kendi hatasiyle bir bìnek atı almaşı halinde, umumiyetle pekâlầ bì çift atına ihtiyacı olduğunu ve böyle bir binek atı almak istemediogini isbat edebilecektir. Bununla beraber mahkemeler yukarda gösterdiğimiz misallerde de olduğu gibi mukavelenin feshini reddedeceklerdir. Infro (P. 38 Note 2). Bütün bu meşleler ig̣in hukukî muamelelerin tefsìri hakkındaki (de l'interpratation des actes juridiques privés 1905 tarihli etüdâmüze bakınz. P. 1218 et. s). 
Bazan kusur hesaba katılması icap edecek derece ağır görülüyor. Bu vaziyetie mukavelenin feshini reddeden yargıçlar bu reddi doktrin kaideleriyle uzlaştırmak için; mesela, hatanın hakikaite mukavelenin feshine hükmedilmesi mutad olan hallerdeki kałar kuvvetlice isbat edilmiş olmasma rağmen; onun subut bulmadığını ileri sürmek gibi bazı çarpaşık çareler kullanıyorlar. Nilrayet bazan da, hâkimler bu doktrin prensipleri yerine az çok sarahaten bu diger prensibi «mukavelenin iptali; davacı hatasının başlıca faili olduğu ve bu iptalin dił̌ger tarafın müsbet bir zararını mucip olacağı hallerde: kabul olunamaz koydular. [1]

Açıkça görüldüğü üzere âdil olan bu prensip bu iki nevi sözde hata arasında hiçbir fark yapmaz. Bu metinlere çok aykırı bulunursa mahkemelerden, tekrardan medenî kanunun 1109.1110 uncu maddelerinin doğru bir şekilde tatbikine dönmeleri istensin. O zaman bizde kabul ediyoruz, hukukî hata hakkındaki tezi-

[1] Gayri menkul satışları hakkmdaki aşą̧ıdaki kărara işar edciim: Bir arazinin muhtevagındaki ayıp (défaut de con ¿enạnè) ałıerya sözieșmeden rucu selâhiyeíi vermiz, $m$ gerer $k i$ bu tarla (satici iarafindan bilinen $b$ tlirli bir iş ięin alınmış olsun $v$ s bu muhtevddaki ayı ona bı işe elvırişsiz bir hale soksun. Bir arazinin bir mürur hakkı ile takyij edilıiş olduğunun saklanmıs bultunınası bir ayıp teşkil etmez, bumun tahkiki satış mukavelesini imzadan evvel alıclya düşerdi, (Cass. 18/Haziran/1902, gü. des Trib. 20/Haziran/1902).

Tiearethanelerin (Fond de Commerce) satışı lałkkında verilmis olan bir kararda da her ne kadar mahkemeler bu ticar hane satılsarnda alıclarl, sattelların yapması mümkün hilelerden korumkkla mzïkstlef is alkelar tarafından inukavelenin imzasindan evvel yapilması kolay araş irmalarla bu hilelerden kurıulmanın mümkün oldrğ hallerde mëdahale etmenelidirler. Zaten, bu müşterilerde sırf kendi ihn̆alleri ile hataya dësmüş̧ürler» denilmişii. (Trib. Comm. La Havre 25/Haziran/1900 rec. du. Havre. 1900. 1. 76). Ayni şekilde taksitli satışlarda da ( $v \geq n$ ie a' iemperampet de valeurs à lot) satış mukavelesinin iptal talebi; alıchmm bilgisiz olmamaș ticaret hayatinda muayyen bir tecrübe sahibi buluhması, taahhütlerinin maliyet ve şumulünü anlyyacak bir durumda olması ve zamanında malûmat elde: etmemiş olmasının sırf kendi ihmalinden ileri gelmiş bulunmasından; alıcinın ruzasin haten beyan ettiği bahanesiyle kabul edilen ez" denilmişi. (Trib. Civ, L $\ominus$ Pry, 4/Ocak/1900, Gaz. Des. Trib. 17/Mari/1900. Savingy ninde işaret ettiği gibi aydınlığa ęlkarmağa ęalışiğını bu prensip, eskiden beri zaten Digesta da meveuttu: (Facti ignorankia ita demum cuique non nacet, si non ei summa negligentia objiciatur : quid enim siomnesin civitateneiant, qaod ille solus ignorat et recte labec definit seiantian neque curiossisimi, neque negligentissimi homini accipiedam: verum ejus. qui eam rem diligenenterinquirende notam habare possits liv. 22. t. vi, $\mathrm{L}$. 9, § 2 v. au même titre la loi 6). 
mizden doğru olmiyan neticeler çlkanlabilir, fakat ayni şekilde fiilî hata hakkında da böyle sonuçlar çıkarmak mümkündür. Son olarak iki şktan biri ya metinlerin harfi harfine tatbiki, adalete (équité) tercih edilir ki bu taktirde bu uygulama tarzının her nevi hâta içinde kabulü lâzımdır; yahut ta adalet, metinlerin harfi harfine uygulanmasına tercih edilir ki bu taktirde de bu tatbik tarzını her nevi hata içinde tercih lâzımdır.

Şimdi medenî kanunun diğer metinlerini incelemek için 1109 - 1110 uncu maddelerini bir tarafa burakalım :

549,2265 ve 2279 uncu maddeler hakkında yargıtayın kararlarına dayanarak etüdün birinci kısmında göstermiş oldư̆umuz iki kararla bize itiraz ederler. Elbette ki bu delil ihmal edilecek mahiyette değildir. Fakat biz de buna karşı kıymeti bundan aşă̆ı kalmiyan ve otoriteye dayanan diğer bir delille cevap vereceğiz, Içlerinden bazlları yargıtay üyeliğinde bulunmuş veya halen de bulunmakta olan büyük muharrirler de bizim fikrimizdedirler. [1]

Fazla olarak mevzuubahis kararların oldukça eski olduğuna da işaret edelim: 14/Ağustos/1882 ve $11 / 0$ cak/1887. Yirmi senede ne fikirler dȩ̧işir, ne kadar insanlar birbirini takip edip geçer. Zamanla yüksek mahkeme üyelerinin bugün büyük bir kısım

[1] Cf. Aubry Rau (5 edit), t. E $\$ 28-$ adde 460 texte et note $7 \$ 206$, texte 2 No, et note $12 \S 218$, texte No. 2 et, note 29 , Planiol t, 1.2 éd, No. 906 et 1527, Demante, t. 11, 385, bis, Decolombe t. $1 x, 609$, Laurent, t. vi, 218-V. Aussi Rennes 19/Mart/1849, S. 50.2.610, Toulous, 27/May1s/1878, S. 80. 2.5 .

Meselâ, 549 uncu maddedeki gibi, iktisabın, kamu intizamına aykım batıl bir mukaveleye istinat etmesi halinde ne sekilde hareket edilmesi lâzım geldiğinde tẹeddüt edilmektedir. (V. Aubry et Rau op. clt. t. 11 P. 409 no: 14 ).

Bizim fikrimize göre eğer iktisabm sebebinde ahlâka mugayir cihetler varsa burada hüsnüniyet kaidelerinin nazari itibare alınmasına mahal yoktur. Fakat aksi halde 549 uncu madde kabili tatbiktir. Bizes Aubry ve Rau 2279 uneu mad. hakkunda çok doğru olarak zilyetlił̧in hüküm ve neticelerini zilyedin hüsnüniyet veya hüsnüniyetiyle ilgisi olmadı̆̆ın söylerler. (Op. clt. t. 11. P, 157, note 29) ve istihkak davasının suiniyetli bir zilyet aleyhinde bile mesmu olamyacagn fakat bu suiniyetin zilyet aleybine 1382 ve 1383 üncü maddelere müstenit bir istirdat davasinm ạlmasina mâni olamıyacă̆ı fikrinde oldukların da ilâve ederler. Zaten diğer taraftan, biz suiniye $t$ hakkındaki genel prensiplerin hukukî hatayı diğerinden (fili hatadan) ayırmadığını gösterdiğimizi zannediyoruz. M. M. Aubry ve Rau nun şindi işaret ve kabul etmiş olduğumuz teorileri de katî olarak iki nevi hata arasında hiçbir farka yer vermez. 
rr.uharrirlerin de cereyanma katıldığı görüşlerin tesirine kapılrası da muhtemel déğil midir? Zaten bize karşı konan kararlarda "Chambre de requète" tarafindan verilmiştir. Fakat bilindiği üzere "Chambre Civil» in bazan ondan farklı bir anlayıs tarzı vardır. Bilhassa bizim fikrimizde olduklarından dolayı işaret etiğimiz eserlerden bazıları, chambre civil de halen veyahut ta e:kiden üye olanlar tarafından yazılmıştır. Bundan dolayıdır ki egrer bu meseleyi halledecek bu daire olsaydı bize hak vereceğini kabul için ciddî sebepler vard.

Dił̌rer bir nokta daha: Hukukî hâta da, medenî kanunun 549 ve 2265 inci maddelerinin tatbik edilemiyeceğini iddia edenlerin bize karşı koymak için istinat ettikleri kararlarda bunu yalnız platonik bir teyitle (affurmation) iktifa etmişler ve mahkemeler, önlerine gelen meseleye onların; ileri sürdükleri, prensibi tatbikten kaçınmışlardır. Halbuki biraz evvel sözleşmelerdeki hâta dolayısiyle jurisprudence'in tatbik etmeden kabul eylediği prensiplerden ne kadar sakınmak lâzım geldiğinini görmüştük. Bunların nüfuzu (otorité) zayıfttr ve tatbikatçılarda (praticien) bunlara büyük önem atfetmemekle hâkimane hareket etmiş olacaklardır.

2279 uncu maddeye gelince: Aleyhine yargitaya müracaat edilmiş karar bu maddenin müşteri lehine tatbikini, müşterinin hukukî bir hata işlemiş oldư̆undan bahisle kabul etmiyordu; chambre de requete de temyiz talebini reddetmişti. Tezimize muhalif olan bu karar; müsteriye atfedilebilecek olan hatanın hukukî hatadan ziyade fiilî hâta olması bakımından da bizce daha fazla tenkide lâyık görülmektedir. [1]

[1] Olayları kusaca anlatalım : Karaya oturan bir gominin kaptamı geminin bordasuda kalan malları kurtanlabilecek bir vaziyette olduğ halde bura teşebbüs etmeden ve malların acele satılmasma lüzum olmadığ halde màstacelen ve müvekkillerine müracaat etmeden saittırdı. Bu ıalları satın alan müş̧teri hüsnüniyettni ileri sürerek satışın muteber olacağm iddia et.i, fakat bu şartlar iẹinde sözde; hüsnüniyetin hivkukî bir hatada mevzuubahis olamyacağndan bahisle onu haksız (akardılar. Làkin hakikatte mişieri ne diyordu? Bir kapianm lüzum olmadığg halde kendisine nakl için tesislim edilmiş malları satabileceğ̛ini zannetšiğini lni söylüyordu? Hayır, çünkïi bunu iddia etmek, müdafaası mümkün olnıyan bir şeỵi ileri sürmekti. Yarğtay kararınn hüläsa edilmiş oldnğu| Dallosda (D. 83. 1.337) mäşterinin kapìana verilmiş vekâle:in şumulünü (tłrme) bilmedił̌ini zaten

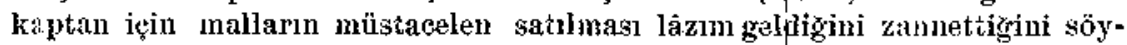
liverek chambre requete in bir kararında ibraz etmiști. Bu kararda yola (Yverişsiz (işliyeniyecek) bir vaziyette olan bir gẹminin antışında; hattâ 
- Bizim anladığımiza göre bu mesele hakkında karar veren yargı̧̧̧lar, müşterinin dürüst olmıyan (indelcat) bir şekilde hareket ettiği zahabına kapılarak, bunun neticesinde belki de kararların hâdiseye kâfi derecede uygun olan mucip sebeplere istinat ettirmek lüzumunu hissetmeden onu haksız çıkarmışlardır. Bize karşı ileri sürülen bu görüs tarzının diğerlerine inzimamı, bu kararın kuvvetini (autorité) gözümüzden epeyce düşürüyor. Her ne olursa olsun bu kararın vüs'atı nedir? Bundan kanunun, bir hataya kurban olanları himaye ettiği her yerde kanun koyucurın yalnız fiilî hatayı mı göz önünde tuttuğu neticesi çıkarılmalıdır? Tabii ki hayır. Cünkü 201, 1109 ve 1110 uncu maddeler gibi bazı metinler yüksek mahkemenin halen kat'î olarak bizim istedił̆imiz şekilde hallettiği kabul olunmalıdır. $O$ halde bazı öyle metinler olacaktır ki, oradaki xhata kelimesi her türlü hatayı ifade edecek ve bazı diğerlerinde ise thata' yalnız fiilî hataya işaret edecektir. Fakat bu tefrik ne için? Nasıl olur da komediyenlerin repertuvar larındaki türlü insanlara göre şahsiyet değiştirdikleri gibi ayni tâbirin kanunun muhtelif kısımlarında mâna değiștireceği kabul olunabilir. Hiç olmazsa bu değişme için bize bir sebep gösterilseydi. Fakat bunun gösierildiğini de duymadık. Umumiyetle kendisine bazı kusurlar atfedilebilecek olan bir mâlik tarafından ansızın takip edilen hüsnüniyetli bir zilyenin vaziyeti bir sözleşme mevzuunun mahiyetinde hata eden bir âkidin ki kadar ve belki de onunkinden daha fazla ilgiye lâyık değil midir?

Doktrininin tesiri altında ümit ederiz ki mahkemelerde yavas yavaş bu görüs tarzına iltihak ederler ve hüsnüniyetli kimsenin fiktıvman sanki suiniyetli imiş gibi telâkki edilmesini kabul etmezler, Code Civilin hükümlerini en insanî mânada anlarlar, bazı adaletsizlikleri elzem kllan sözde sosial zaruretlerin tesirinde kalmadan gözlerini bu çift ideale adalet ve hakikate doğru çevirirler!

Adalet ve hakikat! Hiç şüphesiz ki therkes kanunu bilir addolunur" kaidesi (Hukuk meseli) bizi bunlara doğru götürmez. Etüdümüzün sonuna yaklaştığımız şu sırada, bu kaideden; yani

bu yola elverişsiz (işliyemiyecek) vaziyełt to olmann yersiz yere beyan edilmiş olmaøı halinde dahi hüsnüniyetli müş̧teriye tam bir hak verir» diyordu. (3/Nisan/1867, D. 68. 1. 35). Hukuken bu vaziyet; mevzuubahis ettiğimizin aynıdı, buna rağmen yargı६ların müş̧eriyi haksız @̣karmaları mnhtemel olarak mallaşın kıymętinin çok az takı̌̉r edilmesinden ileri gelmiştir. 
bu başka hiçbir prensip tarafından haklı gösterilemiyecek kaideden doğrudan dogrruya çıan neticelerin heyeti umumiyesi üzerine bir göz gezdirmek yerinde olur. Bu neticeler hangileridir?

Evvelâ ceza mahkemeleri önünde, suçlunun; hiçbir zaman kanunu yanlıs tefsir ettiğini iddia ederek hatasının zarurî oldugunu isbat etmesine müsaade edilemiyecektir. Halbuki bu adalete mutaliftir.

Sonra yine bu mahkemeler önünde mahzur görülebilecek bir hukıkî hatada cezayı azaltıcı bir sebep olarak ileri sürülemiyecektir. Halbuki bu adalete muhaliftir.

Hususî hukuuta, zarurî olan bir hukukî hatanın, başkasına verniş olduğu zarar tam olarak tazmin edilecektir. Halbuki bu da adalete muhaliftir.

Medenî hukukun, bir kusurun hüküm ve neticelerini onun ağırlık derecelerine göre tayin ettiọ̆i hallerde de mahzur görülebilir bir hukukî hata hiçbir zaman kusurun ağırlı̆̆ını azaltmıacakt:r. - Bu da adalete muhaliftir.

Sizi ciddî bir zarara sokan, bir hukukî hata işlemenize müsaade eden veya sizi bir hukukî hâta işlemiye sevkeden bir üçüncü şahıs hiçbir suretle sizi tazminle mükellef tutulmıyacaktır. - Bu da adalete muhaliftir.

Nihayet kanunun bir hataya kurban hüsnưniyetli șahıslara hususî bir himaye bahşettił̧i her halde bu himaye bir hukukî kaide: üzerinde hata etmiş olanlara karşı reddedilecektir. Buda adalete muhaliftir.

Evvet bütün bunlar adalete o kadar muhaliftir ki doktrin ve jurisprudence bu neticeleri çok defa hiç olmazșa kısmen kabul etmiyerek atarlar ve tatbikatçılarda neye dayanacaklarını ve hâlâ ne dereceye kadar sherkesin kanunları bilir addedilmesis lâzım geldiğini tayinde müşkülâta uğrarlar. Fiiliyatta hẹr iki nevi hatayı oldư̛̆u gibi mevcut kabul ederek hukukî hata ile fiilî hata arasında sun'î olarak açılmış bu uçurumu kaldırnhak ve ikisini de ayni umumî prensibe tâbi tutmak, meseleyi ne kadar sadeleştirecek ve bu suretle adalete ne kadar çok daha yaklaşılmış olunacaktır. An'anevi kaide hiç olmazsa nazariye bakımından kabili müdafaa midır? Bunun göstermiş olduğumuz gibi halen yürürlükte olan kanunlarda da hiçbir mesnedi olmadığı gibi mantıken de bu iki nevi hatayı ayırmakta hiçbir sebep yoktur! Yapılması bize 
zorla kabul ettirilmek istenen bu ayrllk bir samya (fiction) dayanır ve bundan dolayıdırki müdafaası bizi hakikatte bir adaletsizlik olan fiktif bir adalete götürür. Klâsik ekonomiye; hakikî insanı değil de kendi hâyal mahsulü olan tamamiyle mücerret bir insan tipi (homo economicus) imal ederek yalnız bu hâyali; incelemesinden serzenişte bulunulưr. Belki klâsik hukukta buna benzer bir serzenişe lâyıktır. Çünkü o da hakikata, bazan ilâveler bazan, retüșler yararak bir nevi hâyali adam yaratur ve yalnız bu adamı tanıdığını iddia ederek yalnız onun mahkemelere girmesine müsaade eder. Bu «Homo Juridicus» (ona bu isimle hitap etmemize müsaade edilsin) hususî bir zihniyete mâliktir, bilhassa kanunları fevkalâde iyi bilmek, en münakaşalı konularda bilgi sahibi olmak hattâ evvelden mahkeme kararlarındaki değişmeleri sezmek gibi büyük bir meziyete de sahiptir. $O$, bize çok kıymetli hukuk dersleri bile vereceğe benziyor. Maatteessüf mücerret olan şeyler dilsizdir, konuşmak için var olmak lâzımdır ki; var olmamakta «Homo Juridicus» un tek kusurudur.

Herkesi. kanunları bilir kabul etmek makul olmak istiyen bir kimse için kendisini; bir hâyale, hukukçunun uydurdư̆u bir nevi yalana kaptırmak, nihayet adaletsiz bir hal çaresine gitmiye mahkûm etmek demektir. Işte bundan dolayıdır ki biz bu eski kaidenin (hukuu meselinin) terkedilmesini ve bundan sonra hakikatın açtığı yolda cessur adımlarla adalete doŭru yürünmesini istiyoruz. 